\title{
Forests and foragers: exploitation of wood resources by Mesolithic and para-Neolithic societies in north-eastern Poland
}

\author{
Agnieszka Wacnik $^{1}$ (D) Witold Gumiński ${ }^{2} \cdot$ Katarzyna Cywa $^{1} \cdot$ Karolina Bugajska $^{2}$
}

Received: 9 July 2019 / Accepted: 10 February 2020 / Published online: 7 March 2020

(c) The Author(s) 2020

\begin{abstract}
Newly acquired palaeobotanical data, including pollen, charred and uncharred wood, provided an exhaustive overview of the temporal changes in woodlands, which changes are due to the cumulative effect of natural processes and the long-term impact of pre-agrarian societies. We used the unique advantage of the peat bog archaeological site at Szczepanki located on an island in the former Lake Staświn (Masurian Lake District) to get an overview of wood exploitation throughout the Stone Age. Special attention was paid to the period of the most intense settlement, the period of the para-Neolithic Zedmar culture. This culture is interesting due to its economy having not been fully recognized so far, especially with respect to the use of plant resources. The evidence from Szczepanki confirmed the use of 16 arboreal taxa, accessible in local woodlands, as a source of timber by foragers. The majority of both unworked wood and fragments bearing traces of processing has been discovered in layers corresponding to the Zedmar period. An important role in the economy was played by wood with medium or low mechanical properties that was however fissile and amenable to woodworking. In addition, other useful properties such as flexibility, lightness, water resistance, strength and ease of splitting were favoured in the selection. The temporal distribution of wood remains in cultural layers at Szczepanki was convergent with a pollen record documenting the course of postglacial migration and local growth of particular taxa, as well as with the archaeologically documented changes in the intensity and time frame of the settlement.
\end{abstract}

Keywords Zedmar culture · Peat-bog archaeological site · Pre-agrarian societies · Vegetation history · Palynology · Charcoal and wood analysis

\section{Introduction}

The diverse use of plant resources and the significance of selected plants for the economy of foragers has often been the subject of scientific discussions in the context of the Mesolithic (e.g. Zvelebil 1994; Bos et al. 2006; Innes et al. 2010; Deforce et al. 2013; Bishop et al. 2015; Warren et al.

Communicated by K.-E. Behre.

Electronic supplementary material The online version of this article (https://doi.org/10.1007/s00334-020-00778-y) contains supplementary material, which is available to authorized users.

Agnieszka Wacnik

a.wacnik@botany.pl

1 W. Szafer Institute of Botany, Polish Academy of Sciences, Lubicz 46, 31-512 Kraków, Poland

2 Institute of Archaeology, University of Warsaw, Krakowskie Przedmieście 26/28, 00-927 Warsaw, Poland
2014; Albert and Innes 2015; Divišová and Š́ída 2015). Until now, much less information has been collected regarding the para-Neolithic societies. The para-Neolithic (synonyms: the Sub-Neolithic, or ceramic Mesolithic or 'Forest Neolithic') is the term introduced by Kempisty (1982) and critically reviewed by Nowak (2007). The economy of these societies, inhabiting vast regions of Eastern and North-Central Europe in the Middle Holocene was based mainly on hunting and gathering, but in some areas limited familiarity with domesticated animals has been confirmed (Gumiński 1995, 1998, 2005, 2012; Timofeev 1998; Dolukhanov et al. 2005). In north-eastern Poland, in the Masurian Lake District the mid-Holocene is characterized by the development of the para-Neolithic Zedmar culture from the fifth to fourth millennium BC (e.g. Gumiński 1999, 2004, 2012).

Knowledge about the long-lasting interactions between past vegetation and hunter-gatherer societies of both the Mesolithic and para-Neolithic periods is limited in Poland to a few peat-bog archaeological sites such as Chwalim 
and Dąbki (Kobusiewicz and Kabaciński 1993; Tobolski and Kubiak-Martens 1997; Kalis et al. 2015) in north-west Poland. In north-east Poland however, in the Masurian Lake District, only the Dudka site, located on the same former Lake Staświn, but on a different island than the currently studied site at Szczepanki, has yielded some knowledge of the history of former vegetation and the Stone Age economy including the utilisation of wood (e.g. Gumiński 1995, 1998, 1999, 2003, 2004, 2005; Nalepka 1995; Gumiński and Michniewicz 2003).

It is worth underlining that Dudka, a southern and eastern settlement at Szczepanki (Masurian Lake District, Poland), and the next three sites from the Prussian Lowland, Kaliningrad District, Russia (Fig. 1; Timofeev 1991, 1998), are the only excavated sites of the para-Neolithic Zedmar culture in the south-eastern Sub-Baltic region (Gumiński 1999, 2004, 2012). As palaeobotanical data from Dudka were not fully published and the data from Russian sites are very limited (Gross 1939; Levkovskaya and Timoveef 2004), our results from Szczepanki provide the first representative and comprehensive palynological, xylological and anthracological record from this part of the Sub-Baltic area of the exploitation of local woodlands by the Mesolithic and para-Neolithic foragers. In the Masurian Lake District, situated beyond the range of the agrarian Linear Pottery and Funnel Beaker cultures, the model of an economy based on hunting, fishing and gathering survived until the end of Neolithic times. On the Zedmar culture sites single bones of domesticated animals, i.e. pig, cattle, sheep and goat also appeared (Timofeev 1991; Gumiński 1998, 1999, 2003, 2004, 2005, 2012;

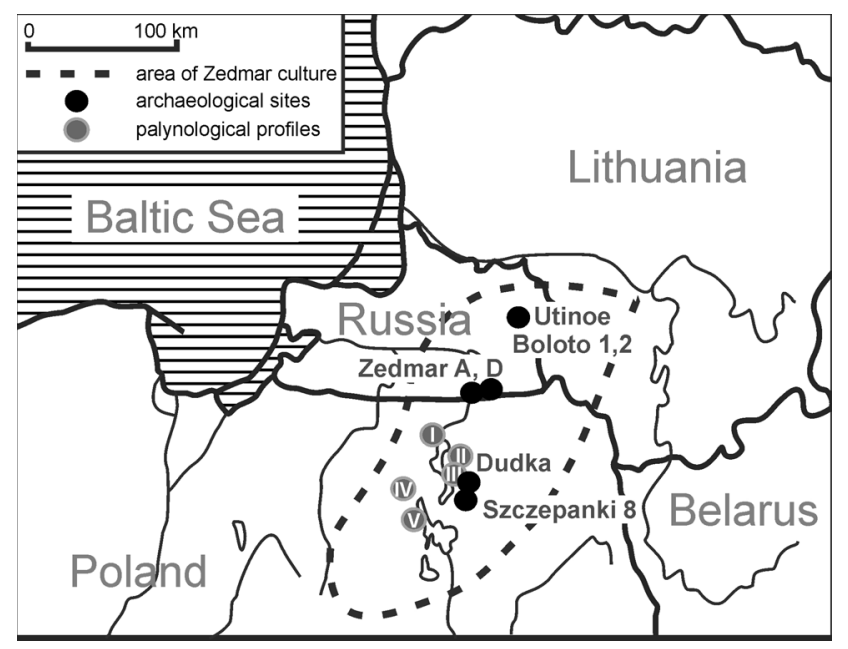

Fig. 1 Location of Szczepanki 8 site in relation to other excavated archaeological sites of the Zedmar culture Dudka, Zedmar A, Zedmar D, Utinoe Boloto 1, Utinoe Boloto 2 and to selected palynological sites mentioned in this study: I-Lake Czarne (KarpińskaKołaczek et al. 2014); II-Lake Kruklin (Stasiak 1963); III-Lake Miłkowskie (Wacnik 2009a); IV—Gązwa (Gałka et al. 2015); VLake Mikołajskie (Ralska-Jasiewiczowa and Latałowa 1996)
Gumiński and Michniewicz 2003; Gautier 2005). The studied site also shows its uniqueness due to the long-distance intercultural contacts (with Southern-Bug-Dniester culture, Moldavia/Ukraine and Slate culture, Sweden; Gumiński 2012). In addition, some extraordinary wooden objects and constructions such as gangboards, a cage for keeping fish and an ornamented paddle found on site, showed the advances of wood technologies in fishing and mobility.

It is accepted that in different parts of Europe pre-agrarian societies had already begun to transform the environment on a local scale so, it is clear that to reconstruct the plant resources exploited by foragers it is important to look at a broader spectrum of palaeobotanical data. The various researchers emphasize that before the introduction of agricultural systems anthropogenic disturbances of plant communities are hardly recognizable in pollen data (e.g. Berglund 1991; Hicks 1993; Kuneš et al. 2008; Mercuri et al. 2013). At the same time, the great potential for palaeoecological studies of past woodlands developed near human settlements demonstrates, for example, dispersed macrocharcoal analysis, since these assemblages represent long-term firewood collection based on an opportunistic strategy (e.g. Asouti and Austin 2005; Théry-Parisot et al. 2010; Moskaldel Hoyo 2012). Furthermore, analysis of sedimentary microcharcoal extracted from peat-bog and lake deposits is an increasingly important source of data reflecting past fire activity also in the context of pre-agrarian settlement (e.g. Dietze et al. 2018; Snitker 2018).

The peat-bog archaeological site at Szczepanki represents a unique type of natural archive, where archaeological assemblages contain both cultural artefacts and large numbers of organic remains preserved in chronological order in sediments, thus offering the best opportunity for parallel studies of settlement history and environmental changes focused on the human impact on local vegetation. The pottery-using Zedmar society attracted our interest due to its specific not fully recognized economy (Gumiński 1998, 1999, 2003, 2004, 2005, 2012; Gumiński and Michniewicz 2003).

Therefore, the following research questions were addressed in this study: (1) what was the character of local vegetation during the human occupation of the island at Szczepanki?; (2) did the foragers exploit local woodlands in a way which led to significant changes of their composition or structure?; (3) was human adaptation to the changing environment reflected in the use of wood resources?; (4) was the raw wood material collected selectively from local woods?; (5) did changes in settlement intensity revealed by archaeological data reflect disturbances of local woods? 


\section{Study site}

\section{Geographical background}

\section{Regional setting}

According to the physiographic division of Poland the studied area is located in the Great Masurian Lake District, which belongs to the Sub-province of East Baltic Lake Districts and generally to the European Plain (Fig. 1). The landform was created during the retreat of the ice-sheet of the Pomeranian Phase of the Weichselian (Vistulian) glaciation (e.g. Marks 2012). The hilly relief with a great number of lakes and depressions filled with mires is the characteristic feature of the region.

The climate represents the coldest lowland climates in Poland with a mean annual temperature of $6.5^{\circ} \mathrm{C}$ (January
$-4.5{ }^{\circ} \mathrm{C}$; July $17.5^{\circ} \mathrm{C}$ ). The mean annual precipitation is $570 \mathrm{~mm}$. The length of the growing season is about 180-190 days (Woś 1999).

\section{Site location}

The Szczepanki 8 archaeological site $\left(53^{\circ} 57.428^{\prime} \mathrm{N}, 21^{\circ} 5\right.$ $9.280^{\prime} \mathrm{E} ; 135 \mathrm{~m}$ a.s.l.) is situated in the southernmost part of the former Lake Staświn (known also as Lake Staświńskie), on one of the several sandy-gravel islands of glacial and fluvioglacial origin (Fig. 2). Lake Staświn was a fairly shallow thaw lake with an average depth of several metres, covering a surface area of about $25 \mathrm{~km}^{2}$ (Gumiński 1995). The size of the former Szczepanki island was ca. $150 \times 100 \mathrm{~m}$. Unlike the other islands, including Dudka, most of the Szczepanki site includes a hill elevated nearly $5 \mathrm{~m}$ above the former lake water level.
Fig. 2 Location of former islands Szczepanki 8 and Dudka. a distribution of palynological profiles and archaeological excavations: sectors $\mathrm{S}$, E, and A: I-Dudka (Nalepka 1995); II—Szczepanki Sz8a/2 (in this study); III-Szczepanki I/2005 (Wacnik and RalskaJasiewiczowa 2008); b location of excavated trenches within sectors S, E, A with number of wood remains in trenches marked, as well as the distribution of studied monoliths $30 \mathrm{~S} 3 \mathrm{~N}$ (in this study), 30E1N (Madeja et al. 2009), and 31E1S (in this study)
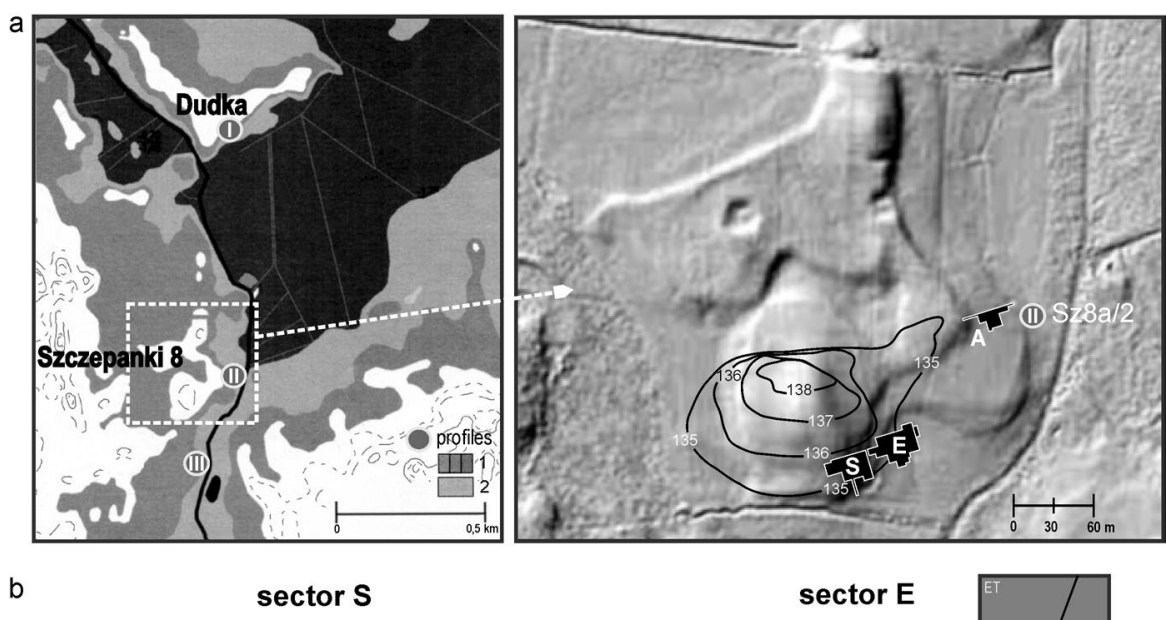

b

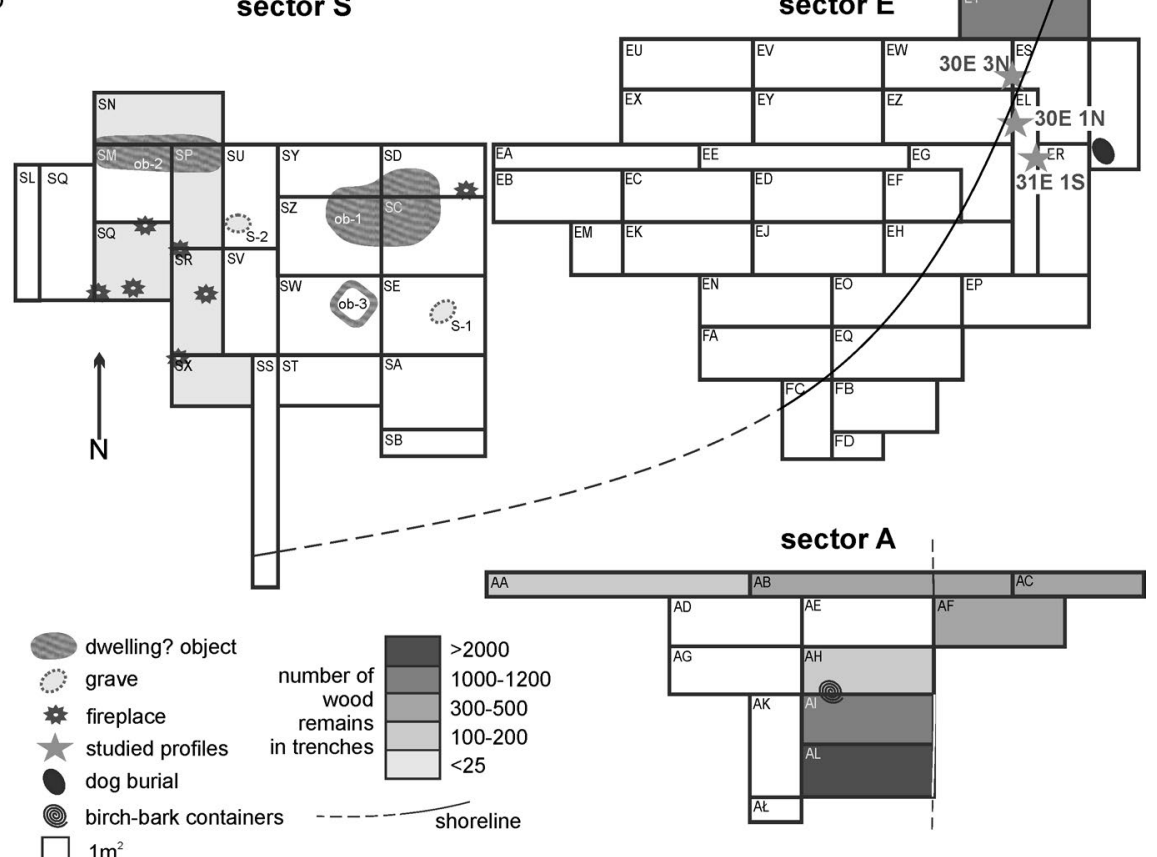




\section{Archaeological settings}

The Szczepanki 8 site includes two separated settlements (Fig. 2) (Gumiński 2004, 2011, 2012, 2016, 2018). The main habitation area of Szczepanki, i.e. the southern settlement (sector $\mathrm{E}$ and $\mathrm{S}$ ), was only occasionally visited during the Late Paleolithic (ca. 11700-9500 cal BC), although some considerable finds and a child's grave (S-2) were discovered (Gumiński 2004; Gumiński and Bugajska 2016). The main purpose for encampment on the island was fishing and fowling (37 and $12 \%$ of all bones respectively).

From the beginning of the Mesolithic a new strategy of settlement and economy appeared, which consisted of seasonal camps, situated on islands and around the lake, changing in a year-round cycle. The Szczepanki island was inhabited mainly in the autumn and winter. Comparing the Early and the Late Mesolithic at Szczepanki, fishing decreased from 46 to $24 \%$ and fowling lost its former (Late Palaeolithic) importance since bird bones constituted only $2.5 \%$ in the Early Mesolithic (ca. 9500-7000 cal вс) and $1 \%$ of the total bone fragments in the Late Mesolithic (ca. 7000-4500 cal BC). Instead, ungulate bones increased distinctly, from $43 \%$ in the Late Paleolithic, through $48 \%$ in the Early Mesolithic, to $65 \%$ in the Late Mesolithic. Ungulates, i.e. red deer, roe deer, elk and wild boar were hunted undoubtedly on the mainland (Gumiński 2004, 2005, 2012, unpublished data).

Although the para-Neolithic Zedmar culture was certainly a direct descendant of the previous local Mesolithic societies of the Maglemosian tradition, they introduced pottery and launched a new style of settlement and economy. From the Early Zedmar (ca. 4500-4000 cal BC) onwards former seasonal camps began to change into stationary settlements probably inhabited all year round. Together with a significant growth of the local population, this resulted in a huge increase in the number and in the diversity of finds, i.e. animal bones, pottery, flint and stone tools, bone and wooden implements, amber ornaments, as well as dwelling objects, fireplaces and burials (Gumiński 1998, 1999, 2004, 2012, 2016, 2018; Gumiński and Bugajska 2016).

At Szczepanki the structure of hunting during the paraNeolithic was similar to that in the Mesolithic, though two important tendencies appeared. The first is the growing proportion of ungulate bones in the following periods, from $71 \%$ in the Early Zedmar, $73 \%$ in the classic Zedmar (ca. 4000-3500 cal BC), 82\% in the post-Zedmar (ca. 3500-2800 cal BC), and 89\% in the Late Neolithic (ca. 2800-2000 cal BC). The second was the opposite tendencya simultaneous decrease in all other categories of game, i.e. fishing from $21 \%$ in the classic Zedmar, through $13 \%$ in the post-Zedmar, to $6.5 \%$ in the Late Neolithic; next fur-bearing animals, from $6 \%$ of all bones in the Early Zedmar to $4 \%$ in the Late Neolithic, birds from 1 to $0.3 \%$ and tortoise from 1.5 to $0.5 \%$ accordingly (Gumiński unpublished data).

It is interesting however, that at Szczepanki the species richness of all categories of game, including fish, rapidly increased from the beginning of the Zedmar time and such a tendency persisted to the post-Zedmar period. Apart from common game previously hunted, from the Early Zedmar onwards additional species appeared: among ungulatesaurochs, wisent and horse; among fur-bearing animalsbrown bear, wild cat, badger, otter, various small mustelids, hare and hedgehog; among birds-forest birds, raptors, big waders and divers; amongst fish-pikeperch, ruffe, eel, and rapfen (Gumiński 2012, unpublished data). It suggests that during the Zedmar periods much more diversified habitats on islands, lake and mainland in the adjacent region were exploited, and/or in different seasons and time.

As it was mentioned above, already in the Early Zedmar single bones of pig, cattle, goat and/or sheep appeared at Szczepanki, but they form 3\% of determined ungulates in the Early Zedmar, $4.5 \%$ in the classic Zedmar, and $10 \%$ in the post-Zedmar and the Late Neolithic (Gumiński unpublished data). Apart from the more complex issue of the status of wild boar or pig, bones of domesticated animals could have come from very small scale local breeding, or rather from long-standing repeated exchange with any Neolithic society (Gumiński 2005; 2012).

At the eastern foreland of Szczepanki island (sector A) in the Early Zedmar time a new dwelling site was established. It was inhabited mainly in the cold season of the year by a very small group of people. Surprisingly, the relationship between the main categories of animals was significantly different to those in the other Zedmar settlements of the same lake-the southern settlement at Szczepanki (sectors E and S) and at Dudka. First of all, at the eastern campsite there were no bones of domesticated animals, not even dogs. The proportion of fish bones (76\%) was as high as that of ungulates at the southern settlement of Szczepanki, and this was almost three times higher than at Dudka and over three times higher than at Szczepanki (Gumiński 2011, 2012, 2016).

In the Early Subboreal some innovations appeared, mainly in technology and the style of pottery. Simultaneously, bone and antler artefacts typical of the Mesolithic and Zedmar culture declined. Accordingly, this period is called the post-Zedmar. Nevertheless, the places and character of campsites, and the local forager economy, remain much the same until the end of Neolithic, when the settlement on the islands of Lake Staświn disappeared.

Later, from the beginning of the Subatlantic phase onwards some slender remains of the Iron Age settlement appeared again by the Lake Staświn. It is noteworthy that even on the same islands, these were located at different sites than during the whole Stone Age (Gumiński 1999, 2004, 2008, 2012). 


\section{Material and methods}

\section{Palynology}

The $295 \mathrm{~cm}$ thick sediment profile $\mathrm{Sz} 8 \mathrm{a} / 2$ was collected with an Instorf sampler in July 2010 at a distance of ca. $15 \mathrm{~m}$ from the archaeological trenches of sector A at Szczepanki (Fig. 2). The sediment was composed of a herbaceous peat at the top, underlined by fine detritus gyttja and silty, sandy gyttja with Equisetum fluviatile macroremains. Samples for pollen analysis of $1 \mathrm{~cm}^{3}$ volume each were taken at $2-5 \mathrm{~cm}$ intervals and prepared by Erdtman's acetolysis method (Berglund and Ralska-Jasiewiczowa 1986). For further details of pollen and microcharcoal counting and diagram construction see Wacnik et al. (2012). Percentage pollen values, as well as the sedimentary microcharcoal concentration, are presented in the diagram drawn on a chronological scale using POLPAL software (Nalepka and Walanus 2003).

\section{Analysis of charred and uncharred macroscopic wood remains}

For taxonomical determination fossil wood fragments were obtained from two sources. The first one consisted of remnants extracted from core $\mathrm{Sz} 8 \mathrm{a} / 2$ and from two monoliths: $30 \mathrm{E} 1 \mathrm{~N}$ in trench EZ, and 31E1S in trench EL, taken with metal boxes from the archaeological trenches. The volume of samples from the trenches varied between 200 and $1,000 \mathrm{ml}$ and only in the case of the core was it limited to ca. $50 \mathrm{ml}$. The samples were processed by flotation and wet sieving using $\varphi=0.2 \mathrm{~cm}$ mesh. The second source of wood was fragments $>0.5 \mathrm{~cm}$, collected manually during the excavations during the years 2008-2012 and inventoried in the same way as all archaeological artefacts. The wood material comes from trenches located within the three sectors S, E and A of the archaeological site (Fig. 2). The dataset includes 590 samples consisting of 6,039 wood fragments; 3,754 charred and 2,285 uncharred. The taxonomic identification was done using atlases of wood anatomy (e.g. Greguss 1945; Freund 1951; Schweingruber 1978; Benkova and Schweingruber 2004) and the reference wood collection of the W. Szafer Institute of Botany, Polish Academy of Science.

\section{Results}

\section{Chronology}

For the profile $\mathrm{Sz} 8 \mathrm{a} / 2$ a depth-age model was constructed (Fig. 3) based on five AMS radiocarbon dates obtained from this profile and calibrated using POLPAL Depth/Age
(Walanus 2015), based on the IntCal13 calibration curve (Reimer et al. 2013). Due to the lack of datings from the Late Glacial part of the profile, the local pollen record from Szczepanki was compared with the reference site for the eastern part of the Great Masurian Lake District-Lake Miłkowskie (8 km from Szczepanki), with the highest number of radiocarbon datings (Czernik 2009; Wacnik 2009a). Palynological markers characteristic for the entire region such as (1) maximum pollen values of Pinus sylvestris at ca. $10800 \mathrm{cal}$ $\mathrm{BC}$ in the Allerød period and (2) maximum pollen values of Juniperus at ca. $10250 \mathrm{cal}$ BC in the Younger Dryas period, were determined and used as a supplementary chronological information (Table 1).

On the archaeological site several biogenic or partly clastic lithological layers were delimited and dated by characteristic archaeological finds, supported by radiocarbon dates (Table 1). The lithological layers are as follows: (1) grey fine calcareous gyttja with mussel shells-Late Palaeolithic, (ca. 11700-11000 cal BC); (2) grey sandy calcareous gyttja-Late Palaeolithic, (ca. 11000-9500 cal BC); (3) beige-grey gyttja with fine detritus and sand-Early Mesolithic, (ca. 9500-7000 cal BC); (4) black-brown coarse detritus with silt-Late Mesolithic, (ca. 7000-4500 cal $\mathrm{BC})$; (5) dark brown coarse detritus with sand, wood fragments and stones-Early Zedmar (ca. 4500-4000 cal BC); (6) black-brown peat with wood fragments and stonesZedmar (ca. 4000-3500 cal BC); (7) bluish-black sediments rich in organic matter or granular peat-post-Zedmar (ca. 3500-2800 cal вс); (8) black peat strongly decomposedLate Neolithic (ca. 2800-2000 cal BC) (Gumiński 2004, 2012, 2018).

\section{Palynology}

The pollen diagram of the Szczepanki profile $\mathrm{Sz} 8 \mathrm{a} / 2$ (sector A) reveals eight zones of plant succession (Fig. 4). The oldest palynological data were correlated to the Allerød Interstadial.

L PAZ Sz 8a/2-1 (Pinus-Betula; ca. 11200-10600 cal вс) is characterized by a predominance of Pinus sylvestris (up to $77 \%$ ), a considerable proportion of Betula (up to $19 \%$ ) and Juniperus (up to $11 \%$ ). Percentage values of Salix (up to $2 \%$ ), Betula nana type (up to $2.6 \%$ ) and Hippophä (up to $1 \%$ ) are low. NAP is generally well represented. The most frequent are Artemisia (up to 6.6\%), Poaceae (up to $6 \%$ ), Cyperaceae (up to 5\%), and Chenopodiaceae (up to $2.6 \%)$. Concentration of microcharcoals is low, below 25,000 particles $/ \mathrm{cm}^{3}$.

The distinctive features of L PAZ Sz 8a/2-2 (JuniperusBetula-NAP; ca. 10600-9500 cal BC) are a maximum of Juniperus (up to 40\%), decrease of subdominant $P$. sylvestris (from 42 to 22\%), higher values of Betula (up to $23 \%$ ), and Salix (up to $3 \%$ ). Infrequent $B$. nana (up to $1.4 \%$ ) and 


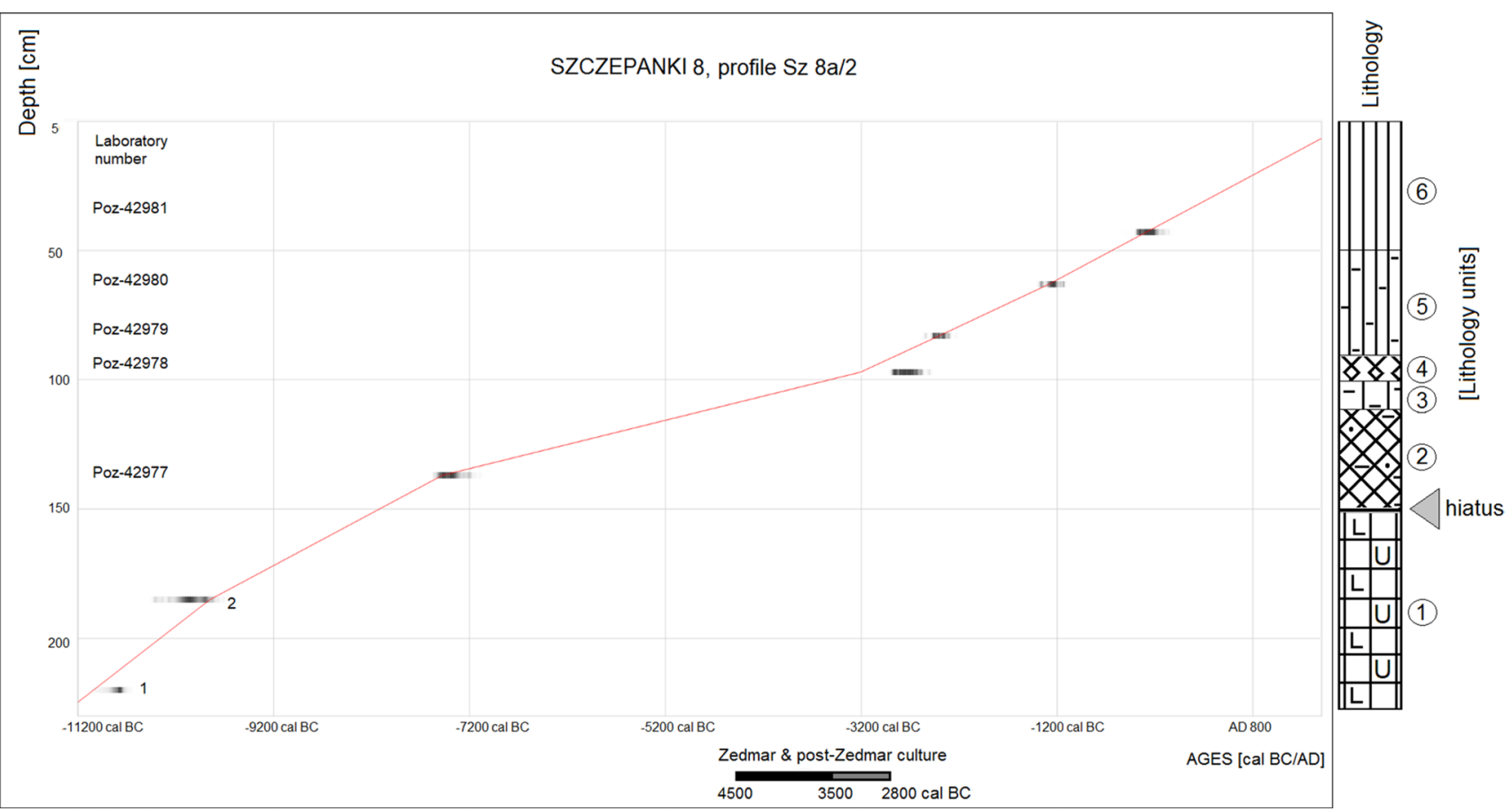

Fig. 3 Szczepanki 8, profile Sz 8a/2. Age-depth model and lithological units. Lithology units: 1 -silty and sandy gyttja with Equisetum remains; 2-sandy detritus gyttja; 3-herbaceous peat with humic substances and detritus; 4-fine detritus gyttja; 5-herbaceous peat with humic substances; 6 - herbaceous peat. Radiocarbon dates from profile Szczepanki Sz8a/2 used in the model construction marked with laboratory numbers: 1-palynological marker of chronology; horizon with characteristic the highest values of Pinus sylvestris pollen; ca. 10800 cal BC; 2-palynological marker of chronology; horizon with characteristic the highest values of Juniperus pollen; ca. $10250 \mathrm{cal}$ BC. For detailed information see Table 1

Table 1 Radiocarbon datings from profile Szczepanki Sz 8a/2 used for the construction of the depth-age model

\begin{tabular}{|c|c|c|c|c|c|}
\hline No & Site and sample name & Type of material & Lab. No & Age ${ }^{14} \mathrm{C}$ вP & Cal age вс (2 $\sigma$-range $)$ \\
\hline 1 & Szczepanki 8; 8a/2; 135-140 cm & Betula sect. Albae fruit scales & Poz-42977 & $8,350 \pm 70$ & $7546-7187$ \\
\hline 2 & Szczepanki 8; 8a/2; 95-100 cm & $\begin{array}{l}\text { Betula sect. Albae fruits, Alnus glutinosa fruit, Urtica } \\
\text { dioica seed }\end{array}$ & Poz-42978 & $4,160 \pm 60$ & $2580-2289$ \\
\hline 3 & Szczepanki $8 ; 8 \mathrm{a} / 2 ; 80-85 \mathrm{~cm}$ & $\begin{array}{l}\text { Betula sect. Albae fruits, fruit scales, Alnus glutinosa } \\
\text { fruit }\end{array}$ & Poz-42979 & $3,920 \pm 35$ & $2549-2293$ \\
\hline 4 & Szczepanki $8 ; 8 \mathrm{a} / 2 ; 60-65 \mathrm{~cm}$ & $\begin{array}{l}\text { Betula sect. Albae fruits, fruit scales, Alnus glutinosa } \\
\text { fruit }\end{array}$ & Poz-42980 & $3,010 \pm 35$ & $1386-1129$ \\
\hline 5 & Szczepanki $8 ; 8 \mathrm{a} / 2 ; 40-45 \mathrm{~cm}$ & Betula sect. Albae fruits, fruit scales & Poz-42981 & $2,220 \pm 60$ & $399-115$ \\
\hline
\end{tabular}

Hippophaë pollen (up to $0.7 \%$ ) are present. Amongst NAP, Poaceae (up to 9\%), Cyperaceae (up to 5\%), Artemisia (up to $13.5 \%$ ), and Chenopodiaceae (up to $3 \%$ ) are the most numerous. Concentration of charred microparticles is very low around 20,000 particles $/ \mathrm{cm}^{3}$ except for one spectrum dated to ca. 9600 cal BC with maximum up to 128,700 particles/ $\mathrm{cm}^{3}$.

In the next L PAZ Sz 8a/2-3 (Betula-Pinus; ca. 8800-8100 cal BC) a sharp increase of Betula (up to 41\%) and also $P$. sylvestris (from 35 to $43 \%$ ) is accompanied by a reduction of Juniperus (to ca. 1\%). Besides the presence of C. avellana (up to $10 \%$ ), Ulmus (up to $4 \%$ ), Alnus pollen
$(<1 \%)$ is also noted. NAP is less frequent. Concentration of sedimentary microcharcoals is the lowest in the profile around 8,000 particles $/ \mathrm{cm}^{3}$.

In L PAZ Sz 8a/2-4 (Corylus-Pinus-Ulmus; ca. 8100-6800 cal BC) C. avellana reaches its maximum (up to $38 \%)$. P. sylvestris is still subdominant but decreasing (from 43 to $30 \%$ ), together with Betula (from 23 to 16\%). Values of Ulmus (up to 6\%), Alnus (up to 5\%), and Tilia (up to $1.5 \%$ ) increase. The frequency of NAP remains low. Concentration of charred microparticles increases from 13,500 to 70,500 particles $/ \mathrm{cm}^{3}$. 

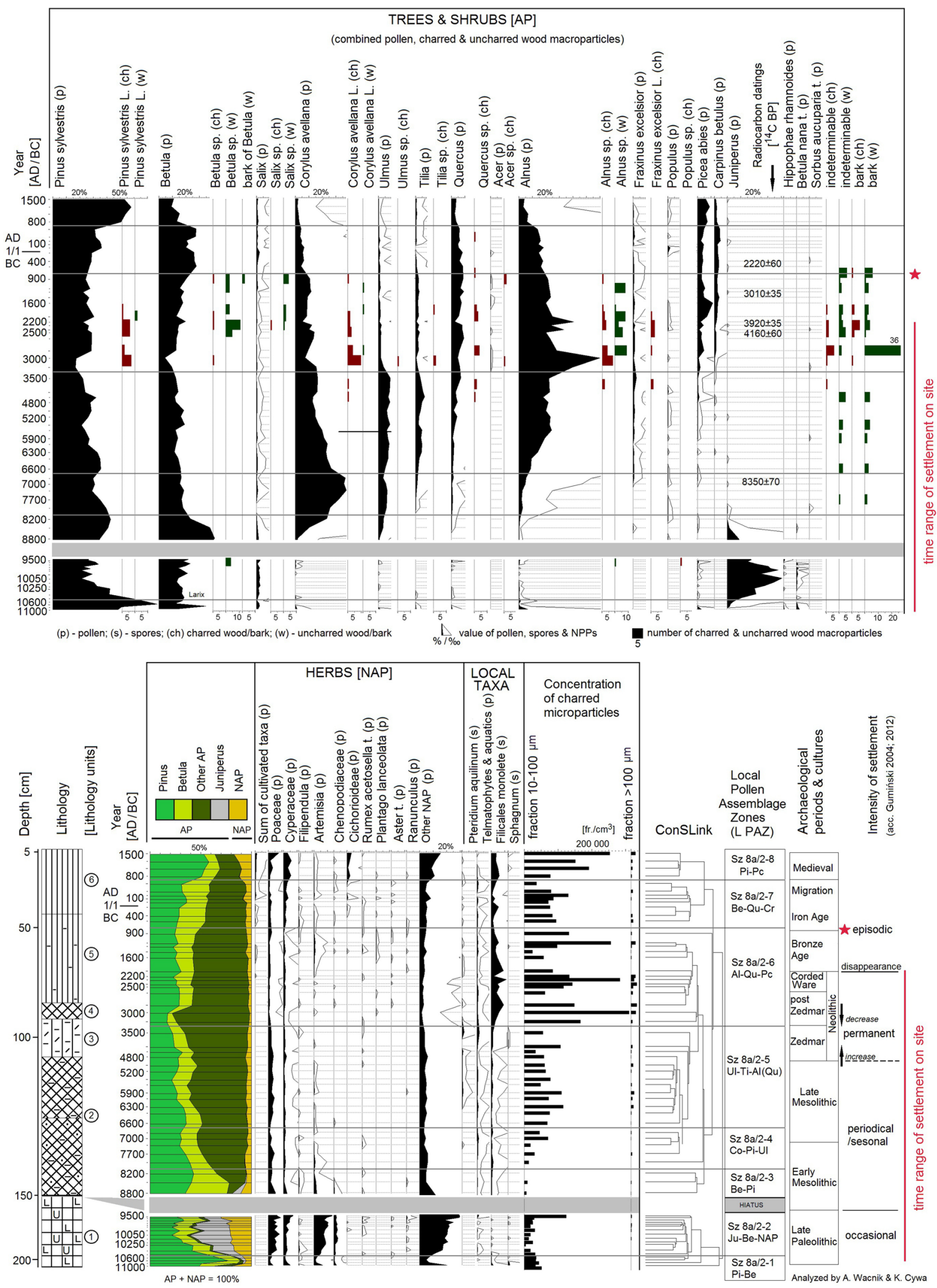

Fig. 4 Szczepanki 8, profile Sz 8a/2. Diagram combining: percentage pollen values of selected taxa, concentration of charred microparticles, counts of charred and uncharred wood as well as archaeological data, drawn on temporal scale. Lithology as described in Fig. 3 
L PAZ Sz 8a/2-5 (Ulmus-Tilia-Alnus-Quercus); ca. 6800-3500 cal BC) is characterized by fluctuating values of P. sylvestris (from 35 to $21 \%$ ) and Betula (from 19 to $11 \%$ ) accompanied by a strong increase of Alnus (from 8 to 24\%). Frequency of C. avellana decreases (from 27 to 15\%). Ulmus (up to 9\%), Tilia (up to 7\%), Quercus (up to 7\%), and Fraxinus pollen (up to $2.4 \%$ ) are visibly more numerous. NAP values remain low, with Poaceae (up to $4 \%$ ) and Cyperaceae (up to $2 \%$ ). Concentration of microcharcoal is significant, around 60,000 particles $/ \mathrm{cm}^{3}$.

In L PAZ Sz 8a/2-6 (Alnus-Quercus-Pinus; ca. 3500-900 cal BC) a distinguishing feature is the highest frequency of Alnus with three maxima (up to 60\%) and Picea (up to $11 \%$ ). Values of $P$. sylvestris (up to $30 \%$ ) and Betula (up to 20\%) increase. A decreasing tendency is noted in case of Ulmus (from 8 to 2\%) and C. avellana (from15 to $10 \%$ ). Quercus (up to 9\%) form a fluctuating curve. Percentage values of Carpinus betulus pollen reach up to $3.4 \%$. Low but increasing NAP is represented by e.g. Poaceae (up to $1.5 \%$ ), Cyperaceae (up to $1.3 \%$ ), and anthropogenic pollen indicators such as Artemisia, Chenopodiaceae, Aster-type, Rumex acetosella-type, Plantago lanceolata, and Cerealia. The highest taxonomic diversity of herbaceous taxa is registered. Concentration of charred microparticles is the highest in the entire profile with the mean value around 170,000 particles $/ \mathrm{cm}^{3}$ and three very high maxima (up to 326,000 particles $/ \mathrm{cm}^{3}$ ).

In the following L PAZ Sz 8a/2-7; Betula-Quercus-Carpinus; ca. 900 cal вС-AD 600) P. sylvestris (up to 36\%), Alnus (up to 18\%), and Betula pollen (up to $27 \%$ ) are subdominant. Values of Picea (up to 4\%), Quercus (up to 9\%), C. avellana (up to $7 \%$ ), and C. betulus (up to 4\%) increase. High diversity of NAP is noted. Concentration of sedimentary microcharcoal decreases to around 37,000 particles $/ \mathrm{cm}^{3}$.

L PAZ Sz 8a/2-8 (Pinus-Picea; ca. AD 600-1500) there is a strong increase of $P$. sylvestris (from 27 to 58\%) and a slight increase of Picea (from 3 to 9\%). Values of Betula (up to $27 \%$ ), Alnus (up to $18 \%$ ), C. avellana (up to 6\%), Quercus (up to $8 \%$ ), and $C$. betulus (up to $4.5 \%$ ) show an opposite tendency. Amongst NAP the value is relatively high of Poaceae (up to $8 \%$ ), Cyperaceae (up to 6\%), Cichorioideae (up to $3 \%$ ), and Cerealia (up to $1.3 \%$ ). A higher concentration of charred microparticles is noted from ca. AD 1100 and reaching up to 220,000 particles $/ \mathrm{cm}^{3}$.

\section{Anthracology and xylology: taxonomical identification of wood macroparticles}

\section{Wood fragments selected by flotation}

Szczepanki 8; sector A, profile Sz 8a/2; sediment core (Figs. 2, 4) Eleven taxa were recognized amongst the charred wood, and only five taxa amongst the uncharred wood. The first finds of uncharred wood of Betula sp., alder Alnus sp. and a single charred piece of wood of poplar/aspen Populus sp. were dated to the Late Palaeolithic (ca. 9650 cal вс). The next determined charcoals did not appear before the Zedmar period (ca. 4500-3500 cal BC) and belonged to hazel Corylus avellana, oak Quercus sp., Alnus sp., and ash Fraxinus excelsior. The taxonomic diversity and number of charred particles were at their highest during the post-Zedmar period (ca. 3500-2800 cal BC), when pine Pinus sylvestris, Betula, C. avellana, elm Ulmus, lime Tilia sp., Quercus sp., maple Acer, Alnus sp., F. excelsior, and indeterminable bark were noted. In the Late Neolithic (ca. 2800-2000 cal BC), charred wood particles of pine, birch, willow Salix sp., ash, hazel, alder, and bark were found. Uncharred wood particles were less diversified and classified as alder, birch and willow. In the younger sediments, ca. 2000-900 cal BC, less numerous finds of fossil wood including charcoals were noted.

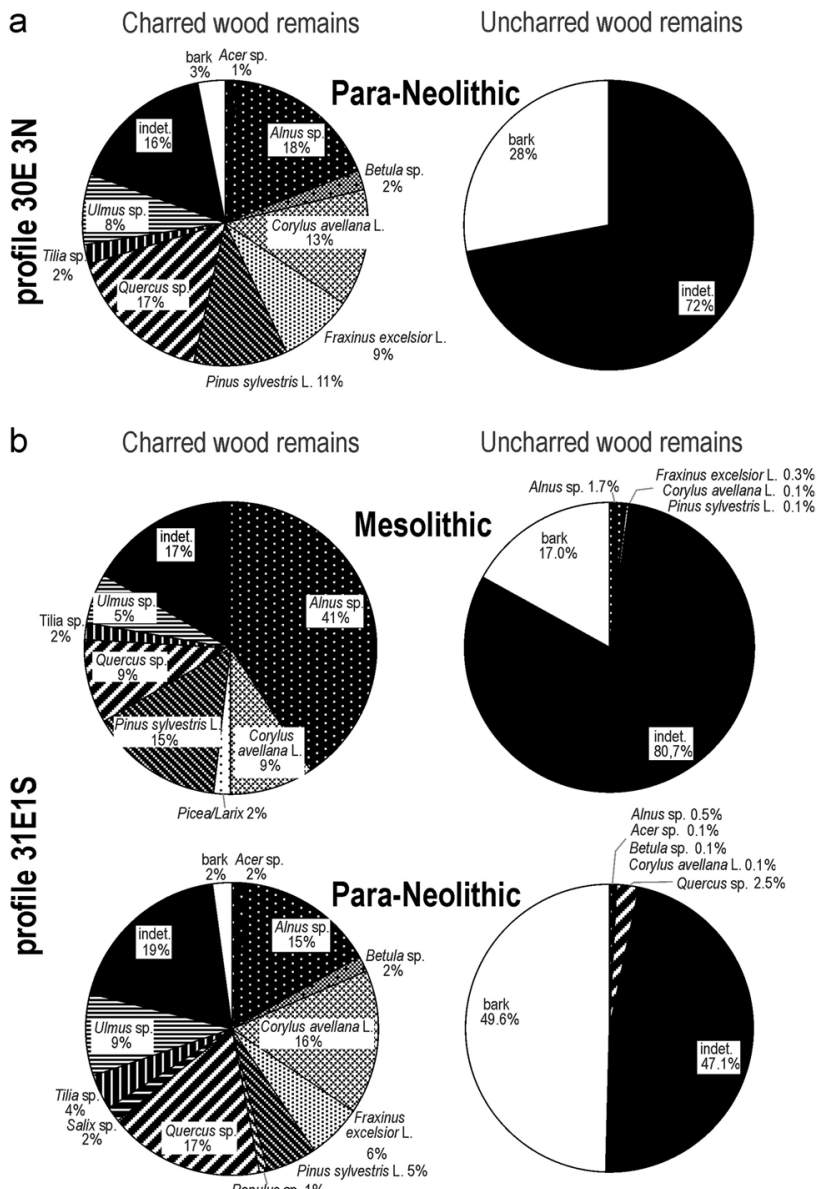

Fig. 5 Szczepanki 8. Percentage values of identified charred and uncharred wood taxa summarized for the Mesolithic and para-Neolithic (including Zedmar; post-Zedmar, and Late Neolithic) periods: a profile $30 \mathrm{E} 3 \mathrm{~N}$; b profile $31 \mathrm{E} 1 \mathrm{~S}$ 
Szczepanki 8; sector E; profile 30E3N; sediment monolith (Figs. 2, 5a; ESM Fig. 1a) The studied profile was composed of calcareous gyttja with plant detritus and sand (105$90 \mathrm{~cm}$ ) archaeologically dated to the Late Palaeolithic and the Mesolithic, and herbaceous peat with sand. This latter part of the profile was dated sequentially to the Mesolithic (90-80 cm), the Zedmar $(80-25 \mathrm{~cm})$, and the Late Neolithic (24 cm-top). Single macroparticles of charred alder and uncharred hazel wood were recorded in the Mesolithic layers. The highest frequency of wood remains was noted in the Zedmar period. The charred wood was represented by nine taxa among which Alnus sp. (18\%), Quercus sp. (17\%), Corylus avellana (13\%), Pinus sylvestris (11\%), Fraxinus excelsior (9\%) and Ulmus sp. (8\%) were the most frequent. Similar taxonomic composition was documented also in the uppermost layer dated to the post-Zedmar and Late Neolithic, but the frequencies of taxa were lower and bark was not found.

Szczepanki 8; sector E; profile 31E1S; sediment monolith (Figs. 2, 5b; ESM Fig. 1b) In the bottom part of the profile calcareous gyttja with plant detritus and sand occurred $(130-110 \mathrm{~cm})$ and was dated based on the archaeological finds to the Late Palaeolithic $(130-127 \mathrm{~cm})$ and the Mesolithic $(127-110 \mathrm{~cm})$. From a depth of $110 \mathrm{~cm}$ the sediment changed to herbaceous peat with sand and was dated sequentially to the Mesolithic, the Zedmar $(73-36 \mathrm{~cm})$, and the Late Neolithic (topmost part) (ESM Fig. 1b). Charred wood particles were represented by 12 taxa while uncharred wood only by 7 taxa. In the Late Palaeolithic layer single pieces of uncharred wood of Alnus sp. and Betula sp. were found. In the Mesolithic macrocharcoals of 10 taxa were determined, among them Alnus sp. (41\%), Pinus sylvestris (15\%), Corylus avellana (9\%) and Quercus sp. (9\%) were the most frequent, though Ulmus, Fraxinus, Populus, Salix, Tilia and larch/spruce Larix/Picea were also present. Indeterminable charred wood reached up to $17 \%$. Among the uncharred particles a considerable number of small twigs of deciduous trees and bark, as well as thin scraps of wood, were found. A further increase in the frequency but similar taxonomic diversity of charred wood was observed in the Zedmar period, when particles of Quercus sp. (17\%), Corylus avellana (16\%), Alnus sp. (15\%), and Ulmus sp. (9\%) were also well represented. Among the uncharred particles, twigs of deciduous trees still prevailed and the number of bark fragments increased up to $50 \%$. In the post-Zedmar and Late Neolithic layers, however, the amount of charred and uncharred wood decreased.

Wood fragments sampled by manual collection from cultural layers (Figs. 2, 6; ESM Figs. 2, 3) As the archaeological site at Szczepanki 8 consists of two settlements, the obtained results are presented separately for each of them. In the first
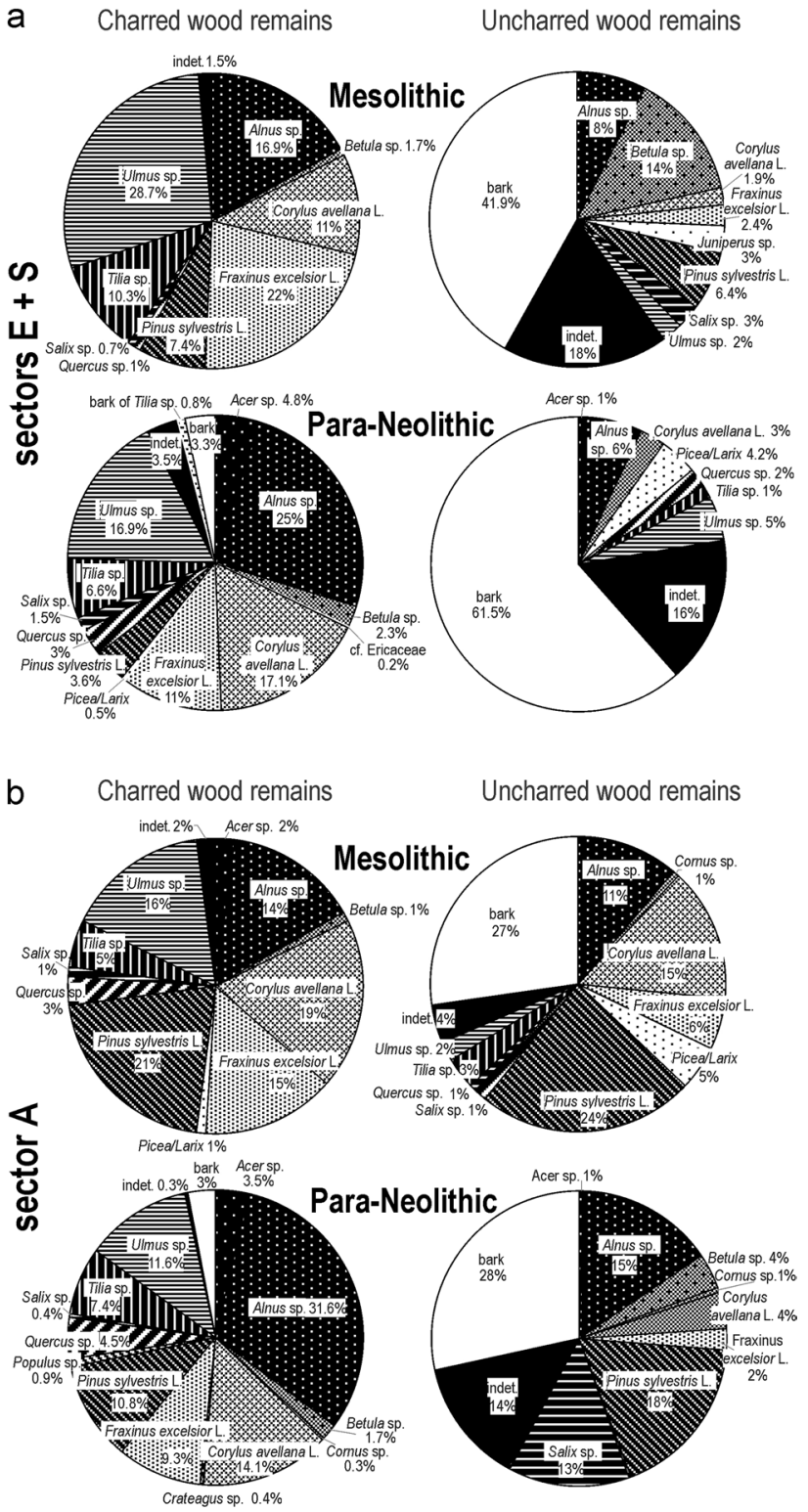

Fig. 6 Szczepanki 8. Percentage values of identified charred and uncharred wood taxa from archaeological trenches summarized for the Mesolithic and para-Neolithic periods: a data from sectors E and $\mathrm{S} ; \mathbf{b}$ data from sector $\mathrm{A}$

settlement, sector S and E (Fig. 6a; ESM Fig. 2), 12 taxa were recognized amongst both charred and uncharred wood, while in the second one, sector A (Fig. 6b; ESM Fig. 3), 14 taxa were documented amongst charred and 12 amongst uncharred wood. The summary image of the temporal distribution of charred wood macroparticles in sectors $\mathrm{E}$ and $\mathrm{S}$ showed that in the Mesolithic layers the most common taxa were elm (29\%), ash (22\%), alder (17\%), hazel (11\%), and lime $(10 \%)$. In the para-Neolithic layers the same taxa predominated but their frequency was different. Elm and ash were less frequent while values of alder and hazel increased. 
Uncharred fragments preserved in the Mesolithic layers consisted of bark and the wood of birch, alder, pine and other less numerous taxa. In the para-Neolithic the representation of uncharred bark increased (up to $61 \%$ ). Among wood only alder, spruce/larch and elm reached values over $4 \%$.

The combined results from sector A showed in the Mesolithic layers the predominance of charred particles of pine (21\%), hazel (19\%), elm (16\%), ash (15\%) and alder (14\%). The frequency of lime, oak, spruce/larch, birch and maple was in the range of $5-1 \%$. In the para-Neolithic layers macrocharcoals of alder, hazel, elm, pine, ash, lime and oak became more frequent. Uncharred wood in the Mesolithic layers was composed mostly of pine, hazel, alder, ash and spruce/larch. The amount of uncharred bark fragments was similar in the Mesolithic and the para-Neolithic layers. In case of the sectors $\mathrm{S}$ and $\mathrm{E}$ charred wood remains were frequent in the Zedmar, but also in the Late Mesolithic and post-Zedmar layers. The remains of uncharred wood predominated in the Early and Late Mesolithic layers. In sector A the highest concentration of charred and uncharred wood, as well as bark, falls during the time of the Zedmar culture development.

\section{Discussion}

\section{Local forest development during the prehistoric human occupation at Szczepanki}

Knowledge of the Late Glacial and Holocene succession of local woodland communities permits confirmation of the availability of particular arboreal taxa in the immediate vicinity of human settlements and allows observation of the temporal changes of human impact on vegetation. Around 11200 cal BC the Lake Staświn area was overgrown with pine-birch woodlands (L PAZ Sz8a/2-1), then in the second half of the Allerød pine prevailed, just as in vast areas of Central Europe (Berglund et al. 1996; Ralska-Jasiewiczowa et al. 2004; Wacnik 2009a; Karpińska-Kołaczek et al. 2014). In the studied region the highest proportion of pine occurs ca. 10800-10700 cal вс (Fig. 1; Lake Mikołajskie; RalskaJasiewiczowa and Latałowa 1996, Lake Miłkowskie; Wacnik 2009a). Open, dry surfaces on the islands and in the lake area were suitable for light-demanding juniper and sea buckthorn, while willow and dwarf birch occurred in moist habitats. Local growth of tree birches was documented in Lake Miłkowskie from ca. $12100 \mathrm{cal} \mathrm{BC} \mathrm{(8} \mathrm{km} \mathrm{from} \mathrm{Szc-}$ zepanki site; Fig. 1; Wacnik 2009a), while presence of pine was confirmed by macroscopic wood remains buried in sediments at the neighbouring Dudka site (Fig. 2) in layers dated to ca. $11060 \mathrm{cal} \mathrm{вс}(11,145 \pm 65$ uncal вP; Ki-5733; elk rib; Gumiński and Michniewicz 2003), corresponding to first visits of hunter-gatherers to the island (Gumiński
1999). Fossil trunks of pine dated to ca. $11300 \mathrm{cal} \mathrm{BC}$ were discovered in Lake Kruklin (9 km from Szczepanki; Fig. 1; $11,390 \pm 210$ uncal вP; Stasiak 1963) and needles as well as seeds appeared in Lake Miłkowskie (from ca. 11250 cal вC; Wacnik 2009a).

Climate cooling at the onset of the Younger Dryas, ca. 10600 cal BC (L PAZ Sz8a/2-2), caused a significant reduction of tree cover, and even initiated aeolian activity in the Dudka and Szczepanki area (e.g. Gumiński 1995, 2003, 2004, 2008). The partial retreat of pine and a development of open birch-pine woodlands with sporadic larch as well as thickets of Juniperus was characteristic for the entire $\mathrm{N}$ and NE Poland in this period. The maximum spread of juniper is dated to ca. 10400 cal BC (Ralska-Jasiewiczowa et al. 2004; Lauterbach et al. 2011) or slightly later at Lake Miłkowskie ca. 10250 cal вс (Czernik 2009; Wacnik 2009a). The landscape was in fact more mosaic-like. Willow grew on the lake and the area of herb-grass communities had increased. Single archaeological finds, e.g. a horse rib $(10,275 \pm 45$ uncal BP; ca. 10090 cal вC; OxA-26654) and an oystercatcher bone $(10,910 \pm 50$ uncal вP; ca. 10800 cal BC; OxA-26651), mark the beginning of the Palaeolithic hunter-gatherers presence at Szczepanki, though their sporadic visits did not leave any imprints on the vegetation.

In the studied profile, a gap in the deposits occurred in the Early Holocene section and most probably resulted from washing-out of sediments due to lake level changes (Gumiński 2008). Analogous, discontinuous sedimentation was observed in Dudka and in another profile from the Szczepanki island (shore Sz 30E1N; Fig. 2; Madeja et al. 2009), contrary to the record from the lake area (Sz I/2005), which was continuous (Fig. 7). Although most of the Early Mesolithic cultural layers were destroyed, however, some archaeological finds confirmed encampments in those times (i.e. a socket-hoe mattock of elk antler ca. $8740 \mathrm{cal} \mathrm{BC}, 9,450 \pm 50$ uncal BP, OxA-26653 and a bone adze from an elk radius, ca. 7340 cal вс, 8,285 \pm 45 uncal вр, OxA-27334). At the beginning of the Holocene, the amelioration of climate favoured a development of woods dominated by birch and pine (L PAZ Sz8a/2-3; Fig. 4), which was accompanied by the reduction of juniper thickets and grasslands. The patches of wet woodlands with downy birch Betula pubescens and willow grew on wet margins of the lake and in the land depressions.

The most distinctive feature of the subsequent phase (L PAZ Sz8a/2-4) was the formation of a new type of scrub woodland dominated by hazel as well as a development of deciduous woodlands composed of elm and hazel, with sporadic oak and lime at the upper, drier elevations. This scenario of local vegetation changes was convergent with the one throughout the region (Ralska-Jasiewiczowa et al. 2004). In the Early Mesolithic a new strategy of settlement and economy was introduced at Szczepanki and Dudka. It relied on seasonal camps used by small groups 


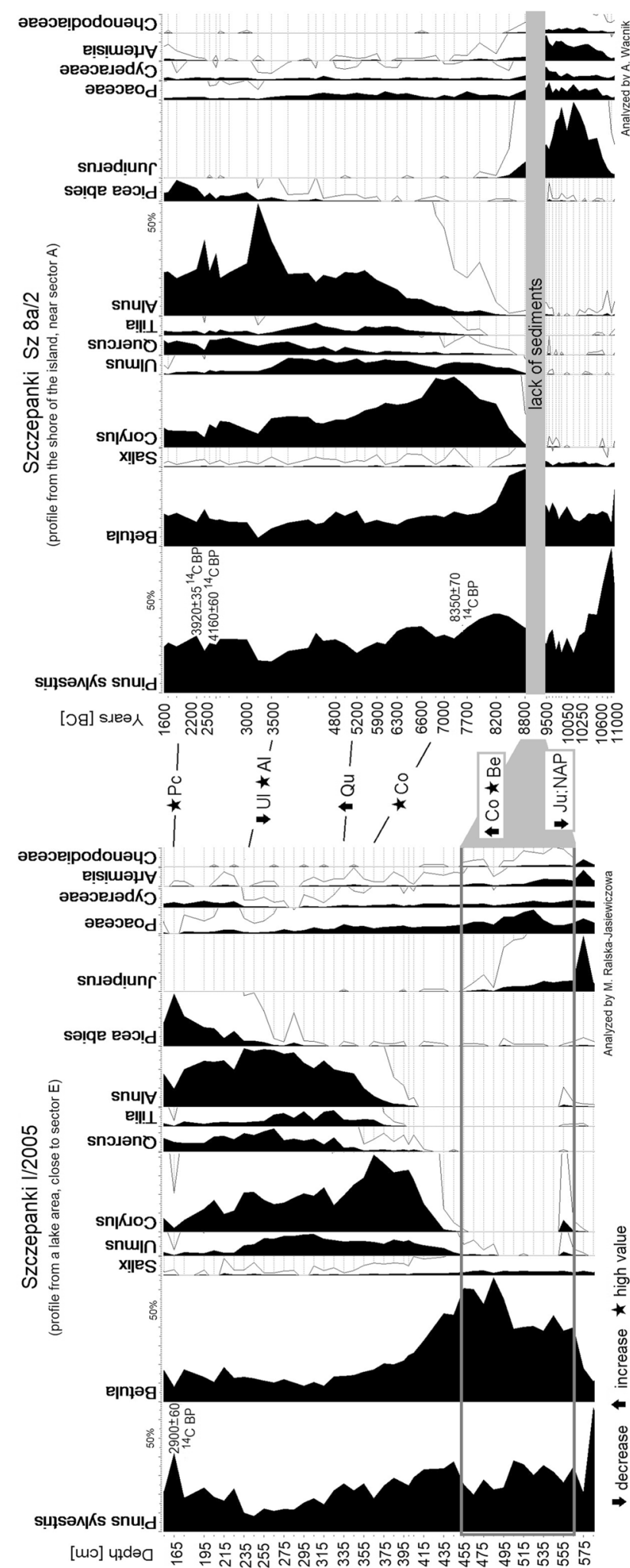

Fig. 7 Correlation of two pollen diagrams from Lake Miłkowskie and Szczepanki, confirming the occurrence of hiatus in profile $\mathrm{Sz} 8 \mathrm{a} / 2$ of inhabitants in a year-round cycle. The impact of human activity was too weak to leave a mark on local woods. Also, the intensive use of hazelnuts known from Dudka (Gumiński and Michniewicz 2003) was not observed at Szczepanki, inhabited in autumn and winter. An increase of sedimentary microcharcoals was observed from the Late Mesolithic onwards (Fig. 4), which indicated recurrent burning and clearance activity delaying woodland regeneration. Herbaceous plants that prefer open habitats, such as Poaceae, Artemisia, Chenopodiaceae, Rumex, and those that expand to fire-affected areas, including Pteridium aquilinum occurred. Woodland clearance led to particular advantages for the propagation of edible plants and facilitated hunting as well as the mobility of human populations (Zvelebil 1994; Mason 2000; Divišová and Šída 2015).

Deciduous elm-lime-oak woodlands with ash and hazel in the understory developed in the middle Holocene ( $\mathrm{L}$ PAZ Sz8a/2-5). Alder woods spread in damp habitats. Drier, sandy ground was overgrown by coniferous or mixed, pine dominated woodlands with oak and birch. Single stands of spruce possibly appeared in the area. The year-round settlement, introduction of small-scale animal husbandry, and population growth during the Zedmar period from ca. 4500 cal BC (Gumiński 1998, 1999, 2004, 2012), brought about further exploitation of woods. This is evidenced by a sharp increase in the number of charred wood and processed wood finds, the highest in cultural layers at Szczepanki (Fig. 4; ESM Figs. 1-3). However, the amount of timber and dead-wood that might have been collected for fuel as well as timber for constructions (such as gangboard or huts) was perhaps too small to be traced in the pollen record. Besides archaeological wood charcoal, a further increase of sedimentary microcharcoal concentration (including fraction of particles larger than $100 \mu \mathrm{m}$ ) indicates a continuation of clearance with fire to free the surface and create favourable environment for people and domesticated animals. The minor impact of human economy on the environment was also associated with the predominance of hunting and fishing as the basis of food supply. Animal husbandry, restricted at Szczepanki to the southern camp, was of little importance as is suggested by the archaeozoological data. The bone remains of domesticated animals at Szczepanki accounted for $3 \%$ of determined ungulates in the Early Zedmar and for $4.5 \%$ in the classic Zedmar (Gumiński unpublished data). In the Zedmar period, bones of cattle and sheep/ goats reached $2.6 \%$ of ungulates at Dudka (7.6\% including bones of semi-domesticated pigs; Gautier 2005; Gumiński 2005). The small scale woodland clearings were marked by an increase in the proportion of Corylus avellana in woods (ca. 4000-3200 cal BC), the beginning of the regular presence of Pteridium aquilinum, as well as a presence of Poaceae and Rumex acetosella (e.g. Vera 2000; Divišová 
and Šída 2015). The possible purpose of these habitats was grazing and browsing of domestic animals.

It is symptomatic that in the Zedmar period, when the occupation of the island at Szczepanki was the most intensive, the human impact on vegetation was still weakly marked in a very local pollen profile (Fig. 4), especially since the coring site was next to the eastern campsite (sector A), inhabited precisely since the Zedmar period. It is likely that this limited visibility of human impact was due to the location of settlements in a heavily wooded environment, causing a masking effect for low pollen producing species in the pollen record. Another explanation can be sought in the character of the economy, based exclusively on resources naturally available in the area.

In the context of an ongoing discussion on the possible introduction of cereal cultivation by Zedmarian society (based mainly on finds of Cerealia pollen in the Zedmar layers on the Russian sites, dated to ca. 3900 cal BC; $5,120 \pm 50$ uncal BP; Levkovskaya and Timoveef 2004), it should be mentioned that no evidence of local cultivation was found at Szczepanki in the classic Zedmar.

The end of the Zedmar culture coincided with a period of climate-dependent transformation of woodland. The changes manifested at Szczepanki (L PAZ Sz 8a/2-6) by the main Ulmus and Tilia decrease (ca. 3500-3200 cal BC), were accompanied by the simultaneous expansion of Quercus, Picea and Carpinus, and the increased acreage of Pinus-Quercus woodland with Picea. These changes followed to a large extent a regional pattern of vegetation changes (Fig. 8; Lake Miłkowskie, Wacnik 2009b; Lake Czarne, Karpińska-Kołaczek et al. 2014; Gązwa, Gałka et al. 2015). Significant changes in Alnus pollen values could have resulted from a development of alder woods especially on the eastern foreland of the island (sector A), since the lake water level rose during post-Zedmar by over one metre and the waterlogged terrain there was flat

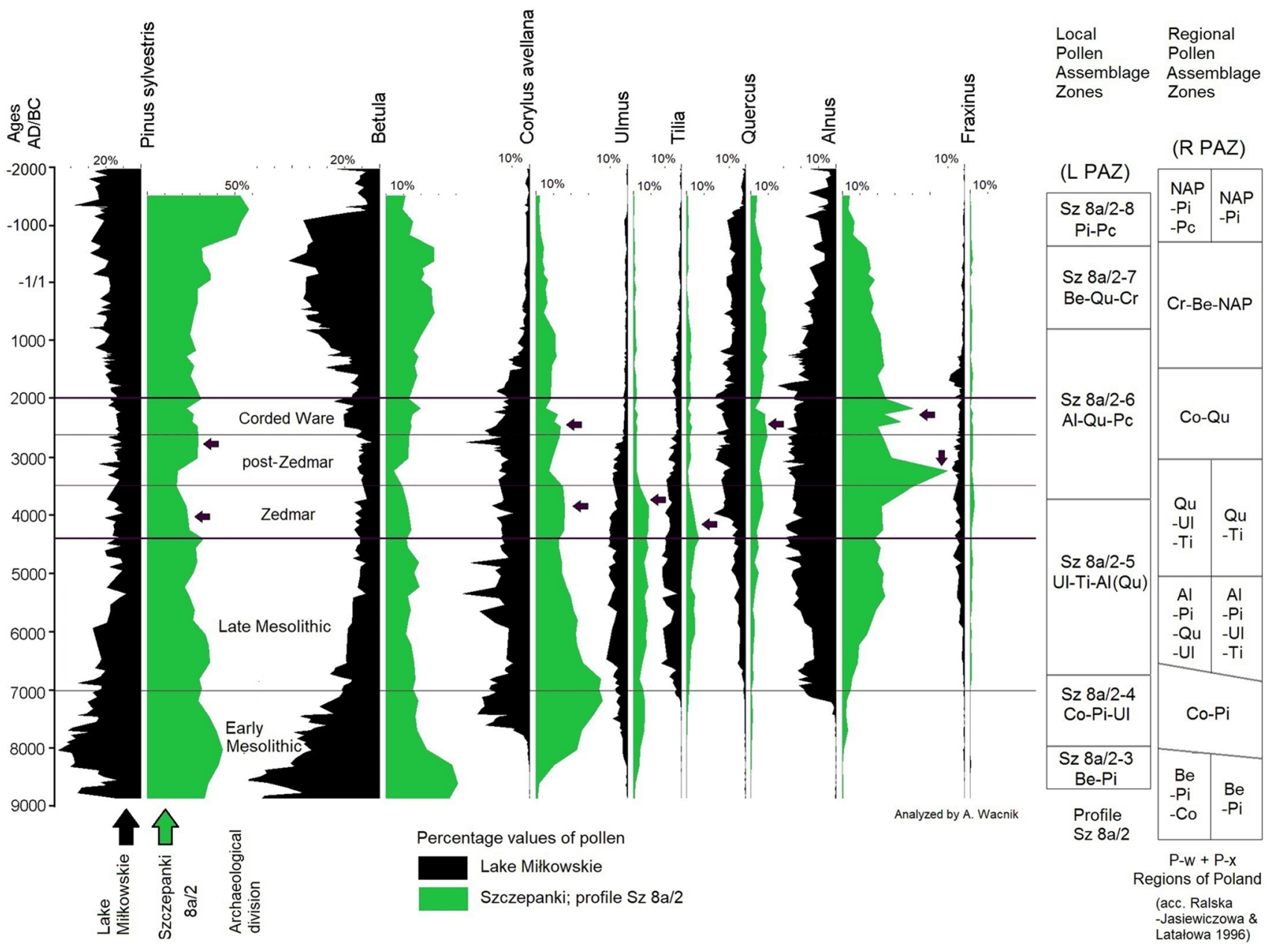

Fig. 8 Correlation of the regional pollen record of vegetation changes from Lake Miłkowskie and the local one from Szczepanki 8. Chronology of the Lake Miłkowskie profile is based on Dietze et al.
(2018). Significant discrepancies between the local record from Szczepanki 8 and regional from Lake Miłkowskie. For further details see Fig. 4 
(Gumiński 2008, 2012). This phenomenon is also marked in the lithology of the studied profile by a re-appearance of gyttja (Fig. 4). The high and short-lasting increase of Alnus pollen, not registered in the region, to some extent could have been an effect of its overrepresentation. Most recognizable local human impact on vegetation, associated with fire use, was again marked by frequent macroand microcharcoals (Fig. 4; ESM Figs. 2, 3). The grazing of woodlands by domesticated animals could have stimulated a development of open habitats with Poaceae, Artemisia, Plantago lanceolata, Aster, and Chenopodiaceae. It is worth emphasizing that bones of domesticated animals at Szczepanki were found in low quantity, amounting to $10 \%$ of all ungulates in the post-Zedmar and the Late Neolithic, respectively (Gumiński, unpublished data). The first Cerealia pollen at Szczepanki were noted in this period and is interpreted as a possible result of an exchange of goods with other Neolithic agricultural societies. The base of the economy (i.e. hunting, fishing and, on a small scale, fowling) remained similar (Gumiński 1998, 1999, 2003, 2004, 2005, 2012; Gumiński and Michniewicz 2003).

Gradual overgrowth of the lake limited the access to the open water body (being also important for fishery) and could have contributed to the gradual decrease in intensity or even disappearance of settlement on the island (Gumiński 2004, 2012). Pollen data corresponding to the final stage of human habitation at Szczepanki 8 in the end of Neolithic showed significant fluctuations in proportions of Corylus, Alnus and Quercus. They were accompanied by macrocharcoals in the archaeological layers as well as high sedimentary microcharcoal concentrations in the peat (Fig. 4), so the clearance of woodland with fire was continued. Woodlands composed of Pinus, Quercus, Betula and Picea together with Alnus woods consistently played important roles in the local vegetation but Carpinus-Tilia-Quercus with Fraxinus, Acer and Corylus were still present. After abandonment of the island, at ca. $2000 \mathrm{cal} \mathrm{BC}$, human activity was still visible in the local palynological record from Szczepanki, though younger archaeological cultures did not locate their settlements there. It is probable that increasing frequency of general open land representatives as well as Cerealia, reflected the existence of settlement on the mainland near the lake. In the Great Masurian Lake District plant cultivation had developed into a leading part of the economy in the Bronze Age (Wacnik et al. 2012). The last episodic prehistoric encampment at the studied site occurred in the Early Iron Age. As wildfires in the mostly humid woodlands were rare, we assume that the youngest macrocharcoals found in profile Szczepanki Sz8a/2 are a sign of short visits.

\section{Spatio-temporal distribution of wood macroremains in cultural layers versus the pollen record of individual arboreal taxa}

In archaeological layers dated to the Late Palaeolithic sparse uncharred wood particles of birch were found in the profile 31E1S (ESM Fig. 1b), as well as charcoal of poplar/aspen (Fig. 4). Alnus macroparticles of wood were most likely displaced from the overlying Mesolithic layers due to the presence of a hiatus in the profile (as local Alnus growth is confirmed by pollen from ca. 8000 cal BC. More arboreal taxa were registered in Late Palaeolithic/Early Mesolithic and Early Mesolithic layers (ESM Figs. 2, 3), where charcoals of Corylus, Alnus, Betula, Fraxinus, Picea/Larix (most probably larch), Salix, Quercus, Pinus and Ulmus were determined. Furthermore, almost the same trees and Juniperus recognized among uncharred wood were growing by the lake shore and on the island. The presence of charcoal indicates the use of unselected timber and dead-wood as firewood by foragers. Only three worked objects made of Pinus and Alnus were found on-site. According to up-to-date knowledge about the postglacial history of plant migration (e.g. Wacnik 2009a; Karpińska-Kołaczek et al. 2014), all the taxa mentioned were a local element of the flora in the Early Mesolithic time (ca. 9600-7000 cal BC; Figs. 6, 7). It should be emphasized, however, that at the neighbouring site Dudka as many as 31 different trees and shrub taxa were identified among charcoal and wood particles collected from Preboreal and Boreal layers (Gumiński and Michniewicz 2003).

In the Late Mesolithic layers at Szczepanki when a higher number of archaeological finds were discovered, the total number of charred particles of Pinus, Ulmus, Alnus, Corylus and Fraxinus clearly increased while Tilia and Acer appeared for the first time. A higher frequency of charcoal particles was noted in profile 31E1S (Fig. 5; ESM Fig. 1), as well as in sector E (ESM Fig. 2).

With the initiation of permanent occupation during the para-Neolithic Zedmar culture, the number of wood fragments significantly increased in different sectors of the archaeological site (Figs. 4, 5; ESM Figs. 1, 2). Most of the arboreal taxa growing in local woods were exploited at least as firewood. However, not all of the trees were used proportionally to their quantities in local communities. For example, charcoals of Fraxinus were quite frequent, though the pollen record shows its low availability in local woods (Fig. 4). The charred remnants of Acer sp., Crataegus sp. and Cornus sp. appeared on-site (sector A; Fig. 6; ESM Fig. 3). Local access to Cornus was documented by pollen and seeds of $C$. sanguinea at Szczepanki (Wacnik, unpublished data). This species was also identified at Dudka as soon as in the early Boreal, and is found until the end of the Atlantic (Gumiński and Michniewicz 2003). In the uncharred fraction Alnus, Pinus and Salix wood prevailed. 
It is probable that they represent trees, which grew on the island itself together with Fraxinus, Populus and Picea as components of woodlands on swamp peat and wet mineral soils.

The taxonomic spectrum of wood remained similar in the post-Zedmar and the Late Neolithic periods, but the number of wood fragments diminished. The decrease of Ulmus, Tilia and Corylus from ca. $3500 \mathrm{cal}$ BC in the pollen sequence was accompanied by the rising number of macrocharcoals of these taxa (Fig. 4). The use of their wood as fuel possibly influenced the natural withdrawal of these taxa from local woods. In the Late Neolithic charred particles of trees such as Alnus, Corylus, Fraxinus, Salix, Quercus, Ulmus, Tilia, Betula and Pinus were recorded (Fig. 4; ESM Fig. 1). The exploitation of the eastern settlement (sector A) distinctly diminishes in the post-Zedmar phase. The top layers contain lots of charcoal, together with sparse finds of small pieces of Late Neolithic pottery, flints and bones, which were predominantly heavily burnt. It was suggested that this part of the island was burnt, perhaps after the disappearance of the settlement (Gumiński 2012).

\section{Usable properties of wood taxa and factors in worked wood selection}

Assuming that unworked wood primarily represents natural vegetation, while wood bearing traces of hand-processing had to be collected and rather deliberately selected by
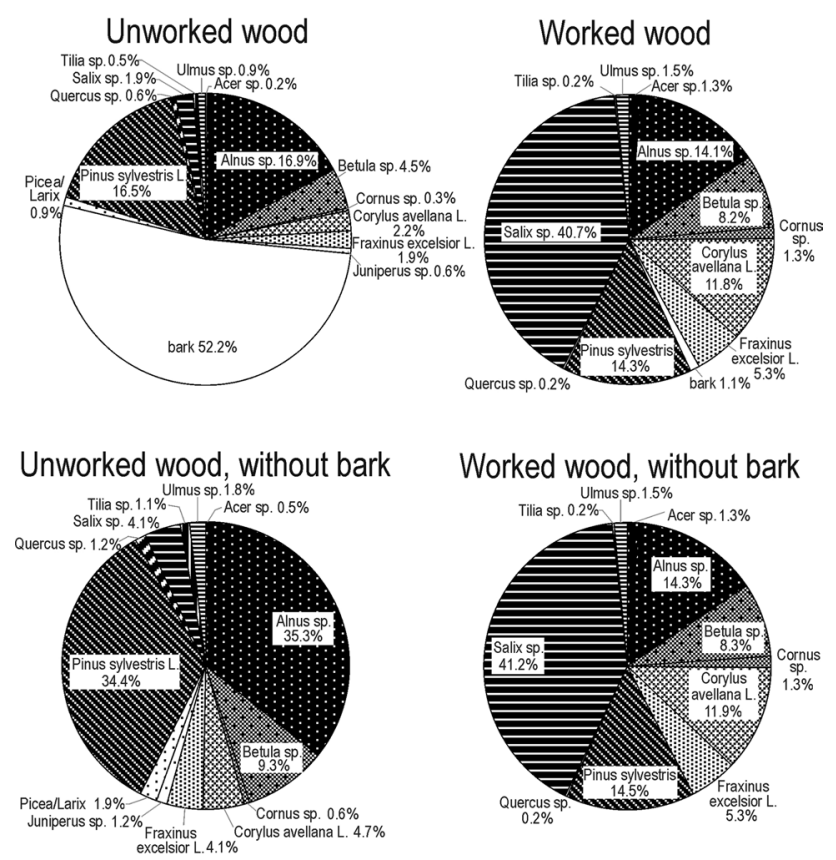

Fig. 9 Szczepanki 8. The taxonomic composition of unworked and worked uncharred wood (with and without bark content) from sectors E, S, and A of archaeological site humans (e.g. Out 2009), the comparison of both proxies can show whether foragers selected wood taxa depending on their purpose or not (Fig. 9).

A large group of uncharred wood and bark pieces bearing traces of chopping and rough-hewing, planing, cutting or drilling (474 findings; $21 \%$ of all uncharred fragments), has been discovered at Szczepanki 8 (Fig. 9; ESM Fig. 4). Most of them were preserved in layers corresponding to the Zedmar culture (377 findings; $80 \%$ of all the worked wood), and only several dozen to the Mesolithic (47 findings), the Late Palaeolithic (22 findings), and the post-Zedmar (28 findings). In the Late Neolithic layers, no worked wood was discovered. So, the temporal distribution of worked wood perfectly reflects the intensity of habitation on the island.

\section{Worked wood: processing and categories of objects}

Among the traces of hand-processing, e.g. wide and slanted cuts made with one stroke of the axe (ESM Fig. 4; 1, 11), as well as surfaces from multiple hewing at different angles (Fig. 10(3, 6); ESM Fig. 4; 2, 12, 13), were identified. Based on the character of processing and the size of the worked wood, several categories of objects were recognized, for example: debarked branches with a diameter of over $3 \mathrm{~cm}$ (ESM Fig. 4; 4), with a diameter of 1-3 cm, e.g. bevelled pegs (Fig. 10(7); ESM Fig. 4; 1, 7) and pegs hewn from many sides (ESM Fig. 4; 2, 4, 6); bevelled smaller twigs with a diameter of $<1 \mathrm{~cm}$ (Fig. 10(5a); ESM Fig. 4; 20). Split wood was a common type of object at Szczepanki. Split planks of 7-8 cm wide and ca. $2 \mathrm{~cm}$ thick (ESM Fig. 4; $22,23)$ were obtained from hazel, pine and alder trunks. Narrow and thin slats made of Pinus wood (Fig. 10(8)) and fragments with drilled holes (Fig. 10(9); ESM Fig. 4; 5, 8, 9, 10) were also recognized. It appears that Salix, Corylus and Fraxinus tended to be selected wood species for making any kind of wooden tackle. Salix and Corylus provided straight rods that distinguish themselves by exceptional elasticity. Such a raw material was certainly desirable for making items such as arrows, spears, bows and fishing-rods. The possible use of Salix wood for making an axe shaft is unlikely due to local availability of hard wood e.g. of Quercus. However, such an unusual use of Salix is known from the Neolithic settlement in Schipluiden (Netherlands) and explained by poor access to better wood in the swampy landscape (Louwe Kooijmans and Kooistra 2006). For the production of simple wooden items, tools, and construction, an important role was played by wood that was not very durable, with medium or low mechanical properties but easily fissile and amenable to processing, such as Alnus. Furthermore, the predominance of round wood fragments with a small diameter can indicate that preserved wood represents mostly leftovers after the cutting of branches or cleaning the trunks. However, it cannot 
Fig. 10 Examples of uncharred wood and bark with traces of woodworking found at Szczepanki 8: 1 concentration of Pinus slats in sediment; photograph by W. Gumiński; 2 excavated and cleaned Pinus slats-cluster of Pinus slats; photograph by K. Bugajska; 3 bevelled peg, Corylus avellana L., Late Mesolithic, no. AF 560/1; 4 branch with slanted cutting, without secondary branches, Salix sp., Zedmar, no. AF 404/62; 5a-wood fragment with square cutout, Alnus sp., b-branch with slanted cutting, Salix sp., Zedmar, no. AF 228/16; 6 sharpened branch, Corylus avellana L., Zedmar, no. AF 600/16; 7 branch with slanted cutting, Salix sp., Zedmar, no. AF 465D/47; 8 slat, Pinus sylvestris L., Late Mesolithic/Zedmar, no. AC $178 \mathrm{D} / 482 ; 9$ fragment of unidentified bark with drilled hole, Zedmar, no. AI 303/13; photographs 3-9 by K. Cywa

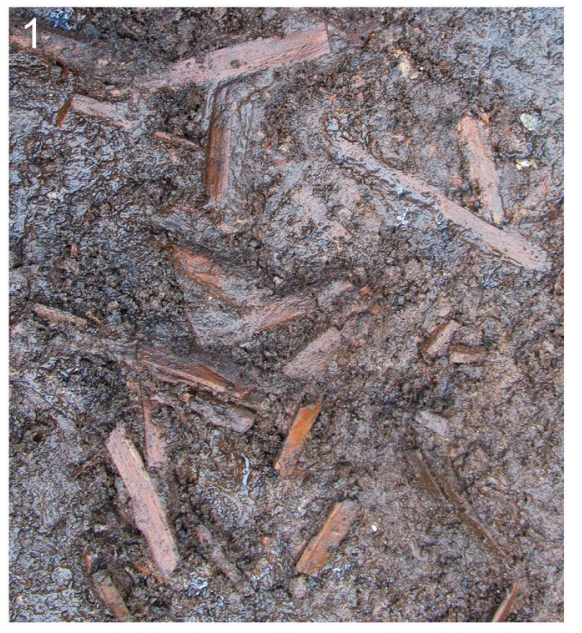

3

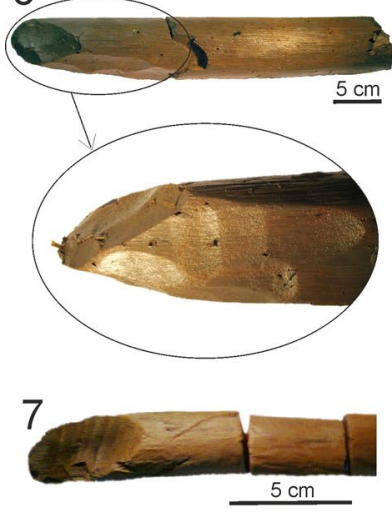

4

8
2

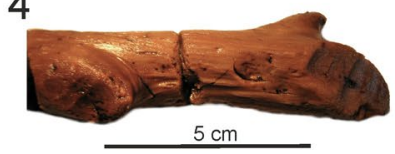

a
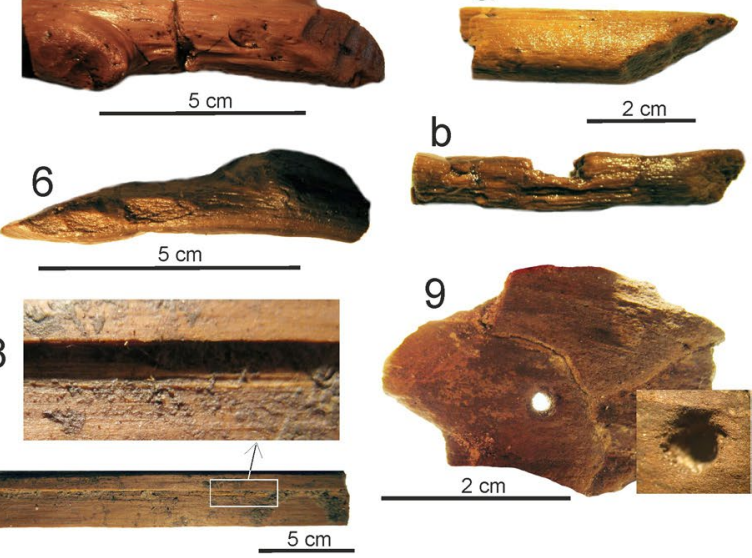

be overlooked that people deliberately cut trees/shrubs with relatively small diameters (due to their requiring less effort).

\section{Trunks and poles for gangboard}

On Szczepanki site Alnus trunks and poles were the most common material used to build a specific scaffolding gangboard to the lake (Gumiński 2012). In the eastern camp (sector A), such a construction dated to the Early Zedmar was supported by big boulders and rows of stones (Gumiński 2012). In the southern settlement (sector E), branches of different wood had already been laid on the shore in the Late Mesolithic and the same spot was built-up with many more logs and huge trunks of Alnus in the Zedmar and post-Zedmar periods, and several Quercus trunks in the Late Neolithic times $(3,980 \pm 40$ uncal вP; MKL-569; ca. 2500 cal BC) (ESM Fig. 5). It is worth noting that at Dudka other types of gangboards were discovered. One of them was a big Pinus tree trunk cut off and laid perpendicularly towards the lake dated to the Early Mesolithic (ca. $8200 \mathrm{cal}$ BC) (Gumiński 2005). The second construction from the Late Mesolithic (ca. 6300-5500 cal BC) comprised floating trunks and branches of different woods, including Alnus, which were mutually interwoven and fixed to the lake bottom by a Quercus pole (Gumiński 1995). At Szczepanki several remains of debarked and cut branches were identified as Cornus.

\section{Slats for fish cages}

Another interesting find at Szczepanki were clusters of at least several dozen slats with a length of 1.5 to $40 \mathrm{~cm}$, made of Pinus, interpreted as the remains of cages for keeping fish alive (Fig. 10; Gumiński 2012, 2016). The average width is ca. $1.5 \mathrm{~cm}$ and thickness $0.2-0.5 \mathrm{~cm}$. The slats are closely standardized and were produced by longitudinally stripping from a Pinus trunk. Each one is a section of 1-2 year growth rings. The slats as such represent a very sophisticated technique of wood working. The remains of binding are not preserved however, some slats have traces of an indent close to their ends. Taking into account the shortness of the slats, as well as the location of the Szczepanki site on the lake island (not on a river) and the rather steep slopes of the littoral, it was suggested that they were remains of cages (creels) for 
keeping live fish. It should be emphasized that the use of Pinus wood in particular was certainly desirable because piscivorous otters avoid its resinous taste, so fish inside the cage were much better protected than in other cages or traps made from rods of Salix or Corylus, although such raw material could have been obtained with far less effort (Gumiński 2016). Seemingly similar clusters of Pinus laths or rods of Corylus and Salix are known from quite a few wetland Stone Age sites in Europe and they are usually rightly interpreted as fish-traps or fish screen-weirs (e.g. Pedersen 1995; McQuade and O'Donnell 2007; Bērziņš 2008; Koivisto and Nurminen 2015; Lozovskaya and Lozovski 2016; Koivisto 2017). Only at Sarnate in Latvia short pine slats were discovered in the form of very compact scrolls and they were reinterpreted as moveable fish-screens (see discussion by Bērziņš 2008). It should be pointed out however, that fish traps or screens have been found almost exclusively on the bed of rivers where the water current leads fish to the trap. Their laths or rods have usually $1.5-2 \mathrm{~m}$ length and were found in situ (often still tied by a cord or strap) in a characteristic deltoid outline (in the case of traps), or parallel (if they were fish-screens). Such circumstances did not exist at Szczepanki. Moreover, concentrations of Pinus slats appeared among the big trunks making up the scaffolding gangboard, which was permanently used as washing site. At Szczepanki slats within aggregations were scattered horizontally as well as vertically. Taking into consideration all the above features clusters of Pinus slats at Szczepanki have been interpreted as cages for keeping live fish (Gumiński 2016).

\section{Ash wood for paddle}

Fraxinus wood was used at Szczepanki, e.g. as a raw material for making a long leaf-shaped paddle, radiocarbon dated to ca. 4200 cal вс $(5,360 \pm 35$ uncal вр; Poz-489443), i.e. to the Early Zedmar (Gumiński 2011, 2012). The paddle is unique in respect of two different features. First of all its blade is hydrodynamically curved, as in modern paddles. It is worth emphasizing, that the blade concavity was derived from its bending (not cutting or scratching-out) most probably by using hot water. The second peculiarity is its decoration. The handle is spirally painted with tar probably with the addition of red-ochre. More diverse items made from Fraxinus wood were found at Dudka, for example a spirally painted fishing-rod, a solid ash-wood club with a purposely chosen slight bend, most probably used for beating fish when they spawn, both dated to the Late Mesolithic (Gumiński 2005), as well as a small fragment of a bilaterally slotted point from the Early Mesolithic (Fiedorczuk 1995). Fraxinus wood is flexible though strong and almost never shrinks under the influence of variable dampness (e.g. Coles 2006; Cywa 2018). This is why it was commonly used for paddles in the Mesolithic (Andersen 1987; Louwe Kooijmans and Kooistra 2006; Louwe Kooijmans and Verhart 2007; Klooß 2010; Out 2017), although considering its hardness and the large dimensions of Fraxinus trees, working with this species required much more effort.

\section{Objects from Betula bark and Salix bast}

Betula bark was used at Szczepanki at least for basket and box making, since fragments of these were found in the Early Zedmar layer at the eastern promontory of the island (sector A) (Gumiński 2012). Moreover, Betula bark as a waterproof material was used as a can for gathering and keeping clear drinking water from a small spring appearing in the same place at the Szczepanki site, though this installation was already being used in the Late Mesolithic (Gumiński 2016). Similar Betula bark boxes are known only from three other Mesolithic sites: Vis I and Nižnee Veret'e in north-eastern Russia, and Friesack in Brandenburg (Oshibkina 1989; Gramsch 1993; Burov 1998), and also from Friesack as containers for drinking water, although in the form of a loxic cone (Gramsch 1998). Salix fibre cord carefully tied and spread evenly with tar was used to fasten the bone fishhook found in the Preboreal gyttja, Early Mesolithic, at Dudka (Gumiński 2005). Salix bast cords or nets from the Preboreal are known only from two other sites: Friesack, Brandenburg and Korpilahti Antrea in the Karelian Isthmus, Finland (today, Russia) (Körber-Grohne 1995; Miettinen et al. 2008). Another use of Salix bast is known from the Late Mesolithic in Russia, e.g. at Zamostje, where Salix ropes were used to fasten elements of two fish traps (Lozovski et al. 2014).

\section{Conclusion}

Anthracological and xylological studies provided a large dataset of 6,039 records, permitting comprehensive insight into the economic use of wood and timber by pre-agrarian societies.

Despite the long-lasting settlement history documented by archaeological finds since the Late Palaeolithic the exploitation of woodlands started in Late Mesolithic and became stronger in the para-Neolithic periods. It was related to the introduction of sedentary occupation, establishment of second dwelling sites, population growth, and diversification of management forms. The basis of food supply remained hunting and fishing supplemented with fowling. The introduction of a small-scale animal husbandry in the Zedmar period influenced the vegetation to a very limited extent. Forest grazing by cattle and sheep/ goats preserved mid-forest openings, providing forage. Although exploitation of woodland as a source of wood by 
inhabitants of the island diminished parallel to the abandonment of Szczepanki and Dudka at the end of the Neolithic, the lake vicinity was also exploited in more recent periods as registered by pollen and microcharcoals.

Charred particles found at Szczepanki were represented mostly by (in order from the most numerous): Alnus, Corylus, Ulmus, Fraxinus, Pinus, Tilia, Quercus, Acer and Betula. Compared with this, among the uncharred particles Pinus, Salix and Betula occurred more frequently as local plants.

The temporal distribution of trees and shrub remains in cultural layers at Szczepanki was convergent with the pollen record documenting the course of postglacial migration and local growth of particular taxa. The wood taxa exploited by humans in particular archaeological periods were accessible in the direct vicinity of the dwellingplace and originated from trees and shrubs growing on the island, in the shore zone or on the mainland. No signs of imports of timber from larger distances were found.

A large group of uncharred wood fragments, bearing traces of chopping and rough-hewing, planing, cutting or drilling (474 fragments; $21 \%$ of the uncharred fragments) has been discovered on the site. Most of them $(80 \%$ of finds) were preserved in layers corresponding to the Zedmar culture, several dozens to the Mesolithic and only over a dozen to the Late Palaeolithic. Most of the worked wood was from Salix, Pinus, Alnus, Corylus, Betula and Fraxinus. Alnus logs served as the scaffolding base for the gangboard to the lake, Fraxinus wood was used to make the paddle, Pinus slats were used to make a cage for fish and Betula bark for making boxes.

The predominance of roundwood fragments of Salix, Pinus, Alnus, Corylus, Betula and Fraxinus with a small diameter was registered. An important role in the economy was played by not very durable wood, with medium or low mechanical properties but easily fissile and amenable to processing. In addition, other useful properties such as flexibility, lightness, water resistance, strength and ease of splitting were favoured in the selection.

Acknowledgements This work is dedicated to the memory of Magdalena Ralska-Jasiewiczowa, a precursor of modern palynological research in Masuria, and a respected researcher for the development of Polish palaeoecology. Authors are very grateful to K. Wasylikowa and M. Moskal-del Hoyo for critical comments on the manuscript, and to G. Wacnik, B. Kurdziel, and students of Archaeology of the University of Warsaw for valuable help, involvement in collecting materials during excavations, and laboratory work. We are also indebted to the reviewers of the manuscript for their comments and improvements. This research was financially supported by NCN funds, Project No. N N304 319636, by the W. Szafer Institute of Botany Polish Academy of Sciences, and by the Institute of Archaeology University of Warsaw through the statutory funds.

Open Access This article is licensed under a Creative Commons Attribution 4.0 International License, which permits use, sharing, adaptation, distribution and reproduction in any medium or format, as long as you give appropriate credit to the original author(s) and the source, provide a link to the Creative Commons licence, and indicate if changes were made. The images or other third party material in this article are included in the article's Creative Commons licence, unless indicated otherwise in a credit line to the material. If material is not included in the article's Creative Commons licence and your intended use is not permitted by statutory regulation or exceeds the permitted use, you will need to obtain permission directly from the copyright holder. To view a copy of this licence, visit http://creativecommons .org/licenses/by/4.0/.

\section{References}

Albert B, Innes J (2015) Multi-profile fine-resolution palynological and micro-charcoal analyses at Esklets, North York Moors, UK, with special reference to the Mesolithic-Neolithic transition. Veget Hist Archaeobot 24:357-375

Andersen SH (1987) Mesolithic dug-outs and paddles from Tybrind Vig, Denmark. Acta Archaeol 57:87-106

Asouti E, Austin P (2005) Reconstructing woodland vegetation and its exploitation by past societies, based on the analysis and interpretation of archaeological wood charcoal macro-remains. Environ Archaeol 10:1-18

Benkova VE, Schweingruber FH (2004) Anatomy of Russian woods. Haupt, Wien

Berglund BE (ed) (1991) The cultural landscape during 6000 years in southern Sweden: The Ystad Project. Ecological Bullentins 41. Munksgaard, Copenhagen

Berglund BE, Ralska-Jasiewiczowa M (1986) Pollen analysis and pollen diagrams. In: Berglund BE (ed) Handbook of Holocene palaeoecology and palaeohydrology. Wiley, Chichester, pp 455-484

Berglund BE, Birks HJB, Ralska-Jasiewiczowa M, Wright HE (eds) (1996) Palaeoecological events during the last 15,000 years: Regional syntheses of palaeoecological studies of lakes and mires. Wiley, Chichester

Bērziñ̌̌ V (2008) Sārnate: living by a coastal lake during the east Baltic Neolithic. Acta Universitatis Ouluensis B Humaniora 86. University of Oulu, Oulu

Bishop RR, Church MJ, Rowley-Conwy PA (2015) Firewood, food and human niche construction: the potential role of Mesolithic hunter-gatherers in actively structuring Scotland's woodlands. Quat Sci Rev 108:51-75

Bos JAA, van Geel B, Groenewoudt BJ, Lauwerier RCGM (2006) Early Holocene environmental change, the presence and disappearance of early Mesolithic habitation near Zutphen (The Netherlands). Veget Hist Archaeobot 15:27-43

Burov GM (1998) The Use of Vegetable Materials in the Mesolithic of Northeast Europe. In: Zvelebil M, Dennell R, Domańska L (eds) Harvesting the sea, farming the forest. The emergence of Neolithic Societies in the Baltic Region. Sheffield Archaeological Monograph 10. Sheffield Academic Press, Sheffield, pp 53-64

Coles JM (2006) Ancient wood, woodworking and wooden houses. EuroREA 3:50-57

Cywa K (2018) Trees and shrubs used in medieval Poland for making everyday objects. Veget Hist Archaeobot 27:111-136

Czernik J (2009) Radiocarbon dating of Late Glacial sediments of Lake Miłkowskie by accelerator mass spectrometry. Acta Palaeobot 49:337-352

Deforce K, Bastiaens J, van Neer W, Ervynck A, Lentacker A, Sergant J, Crombé P (2013) Wood charcoal and seeds as indicators for animal husbandry in a wetland site during the late Mesolithic-early Neolithic transition period (Swifterbant culture, ca. 4600-4000 BC) in NW Belgium. Veget Hist Archaeobot 22:51-60 
Dietze E, Theuerkauf M, Bloom K et al (2018) Holocene fire activity during low-natural flammability periods reveals scale-dependent cultural human-fire relationships in Europe. Quat Sci Rev 201:44-56

Divišová M, Šída P (2015) Plant Use in the Mesolithic Period. Archaeobotanical Data from the Czech Republic in a European Context - a Review. Interdiscip Archaeol 6:95-106

Dolukhanov P, Shukurov A, Gronenborn D, Sokoloff D, Timofeev V, Zaitseva G (2005) The chronology of Neolithic dispersal in Central and Eastern Europe. J Archaeol Sci 32:1,441-1,458

Fiedorczuk J (1995) Mesolithic finds at Dudka 1, Great Masurian Lakeland, and their chronological-taxonomic relations. Przegląd Archeologiczny 43:47-59

Freund H (1951) Handbuch der Mikroskopie in der Technik, Vol 5, Teil 1 and 2 Mikoskopie des Holzes und des Papiers. Umschau Verlag, Frankfurt am Main

Gałka M, Miotk-Szpiganowicz G, Marczewska M, Barabach J, van der Knaap WO, Lamentowicz M (2015) Palaeoenvironmental changes in Central Europe (NE Poland) during the last 6200 years reconstructed from a high resolution multi-proxy peat archive. Holocene 25:421-434

Gautier A (2005) Dudka Island revisited: the general archaeozoological sequence. Przeglad Archeologiczny 53:5-25

Gramsch B (1993) Ein mesolithischer Birkenrindenbehälter von Friesack. Veröffentlichungen des Brandenburgischen Landesmuseums für Ur- und Frühgeschichte 27:7-15

Gramsch B (1998) Mesolithische Wasserlöcher in Brandenburg. In: Koschik H (ed) Brunnen der Jungsteinzeit. Internationales Symposium in Erkelenz 27. bis 29. Oktober 1997. Materialien zur Bodendenkmalpflege in Rheinland 11, Köln, pp 17-23

Greguss P (1945) Bestimmung der mitteleuropäischen Laubhölzer und Sträucher auf xylotomischer Grundlage. Verlag des Ungarisches Naturwissenschaftliches Museum, Hungarian Museum of Natural History, Budapest

Gross H (1939) Moorgeologische Untersuchung der vorgeschichten Dörfen Zedmar-Bruch. Prussia. Zeitschrift für Heimatkunde, Königsberg, pp 101-161

Gumiński W (1995) Environment, economy and habitation during the Mesolithic at Dudka, Great Masurian Lakes, NE Poland. Przegląd Archeologiczny 43:5-46

Gumiński W (1998) The peat-bog site Dudka, Masurian Lakeland: an example of conservative economy. In: Zvelebil M, Dennell R, Domańska L (eds) Harvesting the sea, farming the forest. The emergence of Neolithic Societies in the Baltic Region. Sheffield archaeological monograph 10. Sheffield Academic Press, Sheffield, pp 103-109

Gumiński W (1999) Środowisko przyrodnicze a tryb gospodarki i osadnictwa w mezolicie i paraneolicie na stanowisku Dudka w Krainie Wielkich Jezior Mazurskich (Natural environment and the model of economy and settlement in the Mesolithic and Paraneolithic at the Dudka site in the Masurian Lakeland). Archeologia Polski 44:31-74

Gumiński W (2003) Big game and sparse forest - relations between mammal species and the surrounding environment at the prehistoric fishing Campsite of Dudka in Masuria, NE-Poland. Archeozoologia 21:59-72

Gumiński W (2004) Szczepanki 8. Nowe stanowisko torfowe kultury Zedmar na Mazurach (Szczepanki site 8. A new peat-bog site of Zedmar culture in the great Mazurian lakes region, NE Poland). Światowit 5(46)/B-2003:53-104 (in Polish, with English summary)

Gumiński W (2005) Island, pigs, and hunting places - Comment on preceding paper by Achilles Gautier concerning animal bones of the forager site Dudka. Przegląd Archeologiczny 53:27-51

Gumiński W (2008) Wahania poziomu wody byłego Jeziora Staświńskiego (środkowe Mazury) na podstawie stratygrafii i danych osadniczych (Water level changes in the former Lake Staświńskie, Mazurian Lake District (NE Poland), on the basis of sediment stratigraphy and settlement data). In: Wacnik A, Madeyska E (eds) Polska północno-wschodnia w holocenie. Człowiek i jego środowisko. Botanical Guidebooks 30. W. Szafer Institute of Botany, Polish Academy of Sciences, Kraków, pp 25-45 (in Polish, with English summary)

Gumiński W (2011) Szczepanki, st. 8, woj. Warmińsko-mazurskie. Badania w latach 2009-2010. Stanowisko torfowe łowcówzbieraczy z epoki kamienia (Szczepanki, Site 8, the Warmińskomazurskie voivodeship. Excavations in 2009-2010. The stone age peat-bog site of hunter-gatherers). Światowit 8(49)/B-2009_ 2010:257-261 (in Polish, with English summary)

Gumiński W (2012) Nowe wyjątkowe siedlisko osadnicze paraneolitycznej kultury Zedmar na wschodnim cyplu wyspy Szczepanki (sektor ,A") na Mazurach (A new exceptional dwelling site of the para-Neolithic Zedmar culture in the eastern foreland of Szczepanki island (sector "A"), the Masurian Lake District, NE Poland). Światowit 9(50)/B:87-144 (in Polish, with English summary)

Gumiński W (2016) Szczepanki, St. 8, woj. warmińsko-mazurskie stanowisko torfowe łowców z epoki kamienia. Badania w 2012 roku (Szczepanki, site 8 - a Stone Age peat-bog site of huntergatherers, the Mazursko-Warmińskie voivodeship. Excavations in 2012). Światowit X (LI)/B-2012:323-334 (in Polish, with English summary)

Gumiński W (2018) Stanowisko torfowe łowów-zbieraczy z epoki kamienia. Szczepanki, st. 8, woj. warmińsko-mazurskie. Badania w roku 2016 (Szczepanki, site 8, a Stone Age peat-bog site of hunter-gatherers. The excavations in 2016). Światowit 13-14(5455)A/B-2015-2016:271-278 (in Polish, with English summary)

Gumiński W, Bugajska K (2016) Exception as a rule. Unusual Mesolithic cemetery and other graves at Dudka and Szczepanki, Masuria, NE-Poland. In: Grünberg JM, Gramsch B, Larsson L, Orschied J, Meller H (eds) Mesolithic burials - Rites, symbols and social organization of early postglacial communities. Tagungen des Landesmuseums für Vorgeschichte Halle Band 13/II, Halle (Saale), pp 465-510

Gumiński W, Michniewicz M (2003) Forest and mobility. A case from the fishing camp site Dudka, Masuria, north-eastern Poland. In: Larsson L (ed) Mesolithic on the move. Oxbow Books, Oxford, pp 110-127

Hicks S (1993) Pollen evidence of localized impact on the vegetation of northernmost Finland by hunter-gatherers. Veget Hist Archaebot 2:137-144

Innes J, Blackford J, Simmons I (2010) Woodland disturbance and possible land-use regimes during the Late Mesolithic in the English uplands: pollen, charcoal and non-pollen palynomorph evidence from Bluewath Beck, North York Moors, UK. Veget Hist Archaeobot 19:439-452

Kalis AJ, Kubiak-Martens L, Meurers-Balke J (2015) Archäobotanische Untersuchungen am Mesolitischen Fundplatz Dąbki 9. In: Kabaciński J, Hartz S, Raemaekers DCM, Terberger T (eds) The Dabki site in Pomerania and the Neolithisation of the North European Lowlands (c. 5000-3000 cal B.C.). Archäologie und Geschichte im Ostseeraum 8. Leidorf, Rahden/Westf., pp 31-50

Karpińska-Kołaczek M, Kołaczek P, Stachowicz-Rybka R (2014) Pathways of woodland succession under low human impact during the last 13,000 years in northeastern Poland. Quat Int 328-329:196-212

Kempisty E (1982) Review: T. Wiślański, Krąg ludów subneolitycznych w Polsce (Review: T. Wiślański, Sub-Neolithic societies in Poland). Archeologia Polski 26:436-444 (in Polish)

Klooß S (2010) Wood use and management of the final Mesolithic fishermen-hunter-gatherers on the southern Baltic sea coast. Terra Nostra 10(2):49 
Kobusiewicz M, Kabaciński J (eds) (1993) Chwalim. Subboreal huntergathers of the Polish Plain. Instytut Archeologii i Etnologii Polskiej Akademii Nauk, Poznań

Koivisto S (2017) Archaeology of Finnish wetlands with special reference to studies of stone age stationary wooden fishing structures. Academic Dissertation. Department of Philosophy, History, Culture and Art Studies University of Helsinki, Unigrafia, Helsinki

Koivisto S, Nurminen K (2015) Go with the flow: stationary wooden fishing structures and the significance of estuary fishing in Subneolithic Finland. Fennoscandia Archaeol 32:55-77

Körber-Grohne U (1995) Bericht über die botanisch-mikroskopische Bestimmung des Rohmaterials von einigen Schnüren, Seilen und Netzen von Friesack, Landkreis Havelland. Veröffentlichungen des Brandenburgischen Landesmuseums für Ur- und Frühgeschichte 29:7-12

Kuneš P, Pokorný P, Šída P (2008) Detection of the impact of early Holocene hunter-gatherers on vegetation in the Czech Republic, using multivariate analysis of pollen data. Veget Hist Archaeobot 17:269-287

Lauterbach S, Brauer A, Andersen N et al (2011) Multi-proxy evidence for early to mid-Holocene environmental and climatic changes in northeastern Poland. Boreas 40:57-72

Levkovskaya GM, Timoveef VI (2004) K hronologii i ekologii nachala zemledeliya v Vostochnoj Pribaltike (To the chronology and ecology of the beginning of agriculture in the Eastern Baltic region). In: Problemi hronologii i etnokulturnih vzaimodejstvij v neolite Evrazii. IIMK RAN-Press, St. Petersburg, pp 88-105 (in Russian)

Louwe Kooijmans LP, Kooistra L (2006) Wooden artefacts. In: Louwe Kooijmans LP, Jongste PFB (eds) Schipluiden: a Neolithic settlement on the Dutch North Sea coast c. 3500 cal BC. Analecta Praehistorica Leidensia 37/38. Leiden University, Leiden, pp 226-251

Louwe Kooijmans LP, Verhart LBM (2007) Pebbles and paddles On Rijckholt flint distribution and water transport in the Mesolithic and Neolithic of the Netherlands. In: Hårdh B, Jennbert K, Olausson D (eds) On the road. Studies in honour of Lars Larsson. Acta Archaeologica Lundensia Series in $4^{\circ}$, No 26. Almqvist \& Wiksell International, Stockholm, pp 199-204

Lozovskaya OV, Lozovski VM (2016) The Use of Wood at the Zamostje 2 Site. In: Uino P, Nordqvist K (eds) New Sites, New Methods. Proceedings of the the Finnish-Russian Archaeological Symposium, Helsinki. ISKOS Series 21. Finnish Antiquarian Society, Helsinki, pp 59-73

Lozovski V, Lozovskaya O, Mazurkevich A, Hookk D, Kolosova M (2014) Late Mesolithic - Early Neolithic human adaptation to environmental changes at an ancient lake shore: the multi-layer Zamostje 2 site, Dubna River floodplain, Central Russia. Quat Int 324:146-161

Madeja J, Wacnik A, Zyga A, Stankiewicz E, Wypasek E, Guminski W, Harmata K (2009) Bacterial ancient DNA as an indicator of human presence in the past: its correlation with palynological and archaeological data. J Quat Sci 24:317-321

Marks L (2012) Timing of the Late Vistulian (Weichselian) glacial phases in Poland. Quat Sci Rev 44:81-88

Mason SRL (2000) Fire and Mesolithic subsistence - managing oaks for acorns in northwest Europe? Palaeogeogr Palaeoclimatol Palaeoecol 164:139-150

McQuade M, O'Donnell L (2007) Late Mesolithic fish traps from the Liffey estuary, Dublin, Ireland. Antiquity 81:569-584

Mercuri AM, Bandini Mazzanti M, Florenzano A, Montecchi MC, Rattighieri E, Torri P (2013) Anthropogenic pollen indicators (API) from archaeological sites as local evidence of human-induced environments in the Italian Peninsula. Annali di Botanica Ann Bot (Roma) 3:143-153

Miettinen A, Sarmaja-Korjonen K, Sonninen E et al (2008) The palaeoenvironment of the 'Antrea Net Find'. ISKOS 16:71-87
Moskal-del Hoyo M (2012) The use of wood in funerary pyres: random gathering or special selection of species? Case study of three necropolises from Poland. J Archaeol Sci 39:3,386-3,395

Nalepka D (1995) Palynological investigations of an archaeological site at Dudka (profile D1-26). Przegląd Archeologiczny 43:61-64

Nalepka D, Walanus A (2003) Data processing in pollen analysis. Acta Palaeobot 43:125-134

Nowak M (2007) Middle and Late Holocene hunter-gatherers in East Central Europe: changing paradigms of the "non-Neolithic" way of life. Doc Praehist 34:89-103

Oshibkina SV (1989) The material culture of the veretye-type sites in the region to the east of Lake Onega. In: Bonsall C (ed) The Mesolithic in Europe. John Donald Publishers, Edinburgh, pp 402-413

Out WA (2009) Firewood collection strategies at Dutch wetland sites in the process of Neolithisation. Holocene 20:191-204

Out WA (2017) Wood usage at Dutch Neolithic wetland sites. Quat Int 436:64-82

Pedersen L (1995) 7000 years of fishing: stationary fishing structures in the Mesolithic and afterwards. In: Fisher A (ed) Man and the sea in the Mesolithic. Oxbow Books, Oxford, pp 75-86

Ralska-Jasiewiczowa M, Latałowa M (1996) Synthesis of palaeoecological events in Poland. In: Berglund BE, Birks HJB, RalskaJasiewiczowa M, Wright HE (eds) Palaeoecological events during the last 15,000 years: regional syntheses of palaeoecological studies of lakes and mires. Wiley, Chichester, pp 91-127

Ralska-Jasiewiczowa M, Latałowa M, Wasylikowa K, Tobolski K, Madeyska E, Wright HE, Turner C (eds) (2004) Late Glacial and Holocene history of vegetation in Poland based on isopollen maps. W. Szafer Institute of Botany, Kraków

Reimer PJ, Bard E, Bayliss A et al (2013) IntCal13 and MARINE13 radiocarbon age calibration curves $0-50000$ years calBP. Radiocarbon 55:1,869-1,887

Schweingruber FH (1978) Mikroskopische Holzanatomie. Swiss Federal Institute for Forest, Snow and Landscape Research, Birmensdorf

Snitker G (2018) Identifying natural and anthropogenic drivers of prehistoric fire regimes through simulated charcoal records. J Archaeol Sci 95:1-15

Stasiak J (1963) Historia jeziora Kruklin w świetle osadów strefy litoralnej (History of Kruklin Lake as revealed by the deposits of its litoral zone). Prace Geograficzne 42:7-9

Théry-Parisot I, Chabal L, Chrzavzez J (2010) Anthracology and taphonomy, from wood gathering to charcoal analysis. A review of the taphonomic processes modifying charcoal assemblages, in archaeological contexts. Palaeogeogr Palaeoclimatol Palaeoecl 291:142-153

Timofeev VI (1991) Neolithic sites of the Zedmar type in the southeast Baltic area. In: Jennbert K (ed) Regions and reflections In honour of Märta Strömberg Acta Archaeologica Lundensia Series in $8^{\circ}$, No. 20. Almqvist \& Wiksell International, Stockholm, pp 15-26

Timofeev VI (1998) Cedmarskaia kultura v neolite vostocnoi Pribaltiki (The Zedmar culture in the Neolithic of East Baltic region). Tverskoi archeologiceskii cbornik, pp 225-236 (in Russian)

Tobolski K, Kubiak-Martens L (1997) Dąbki near Koszalin, the state of the palaeobotanical research. In: Król D (ed) The built environment of coast areas during the Stone Age. The Baltic Sea-Coast Landscapes Seminar, Gdańsk, pp 66-69

Vera FWM (2000) Grazing ecology and forest history. CABI Publishing, Wallingford

Wacnik A (2009a) Vegetation development in the Lake Miłkowskie area, north-eastern Poland, from the Plenivistulian to the late Holocene. Acta Palaeobot 49:287-335

Wacnik A (2009b) From foraging to farming in the Great Mazurian Lake District: palynological studies on Lake Miłkowskie sediments, northeast Poland. Veget Hist Archaeobot 18:187-203 
Wacnik A, Ralska-Jasiewiczowa M (2008) Przemiany szaty roślinnej w rejonie kopalnego Jeziora Staświńskiego i jej związek z lokalnym osadnictwem pradziejowym (Development of vegetation in relation to local prehistoric settlement in the fossil Lake Staświńskie (NE Poland). In: Wacnik A, Madeyska E (eds) Polska północnowschodnia w holocenie. Człowiek i jego środowisko Botanical Guidebooks 30. W. Szafer Institute of Botany, Polish Academy of Sciences, Kraków

Wacnik A, Goslar T, Czernik J (2012) Vegetation changes caused by agricultural societies in the Great Mazurian Lake District. Acta Palaeobot 52:59-104

Walanus A (2015) POLPAL DepthAge IntCal 13. https://www.adamw alanus.pl/depthage.html. Accessed 10 Apr 2018

Warren G, Davis S, McClatchie M, Sands R (2014) The potential role of humans in structuring the wooded landscapes of Mesolithic
Ireland: a review of data and discussion of approaches. Veget Hist Archaeobot 23:629-646

Woś A (1999) Klimat Polski (Climate of Poland). Wydawnictwo Naukowe PWN, Warszawa

Zvelebil M (1994) Plant use in the Mesolithic and its role in the transition to farming. Proc Prehist Soc 60:35-74

Publisher's Note Springer Nature remains neutral with regard to jurisdictional claims in published maps and institutional affiliations. 